

Abstract

Underwater ambient sea noise and noise produced by fishing with an otter-trawl was measured with a hydrophone on the sea floor. The noise was analysed in $211 / 3$-octave bands with center frequencies from 3.15 to $315 \mathrm{~Hz}$. Previously published data on the effect of masking noise on cod hearing, and the measured noise levels were used to calculate the ranges at which cod can detect trawling noise at the different frequencies.

The calculations indicate that even in the noisiest ambient, noise likely to occur in the sea, cod can detect trawling noise at 9 miles $(1.7 \mathrm{~km})$ in winter, and at .6 miles $(1.1 \mathrm{~km})$ insurer. The difference is :' attributed to seasonal variation of sound transmission characteristics.

s. 


\section{$l^{\text {Ri: }}$ Résumé}

Le bruit de mer ambiant sous-marin et le bruit aausé par la peche au chalut furent mesurés avec un hydrophone au fond de la mer. Le bruit fut analysé dans $211 / 3$ bandes octaves avec fréquences centrales de 3.15 à. $315 \mathrm{~Hz}$. Les données déjà publiées sur l'effet du bruit masqué en rapport avec l'ouie de la morue, et les niveaux du bruit mesuré furent utilisés pour calculer les intervalles de variation du bruit de chalutage que la morue peut percevoir à différentes fréquences.

Les calculs indiquent que malgré le plus bruyant son ambient. vraisemblable à se produire dans la mer, la morue peut percevoir le bruit de chalutage à .9 mille $(1.7 \mathrm{~km})$ en hiver, et à .6 mille $(1.1 \mathrm{~km})$ en été. La différence est attribuée à la variation saisonnière des caractéristiques de la transmission du son. 

4
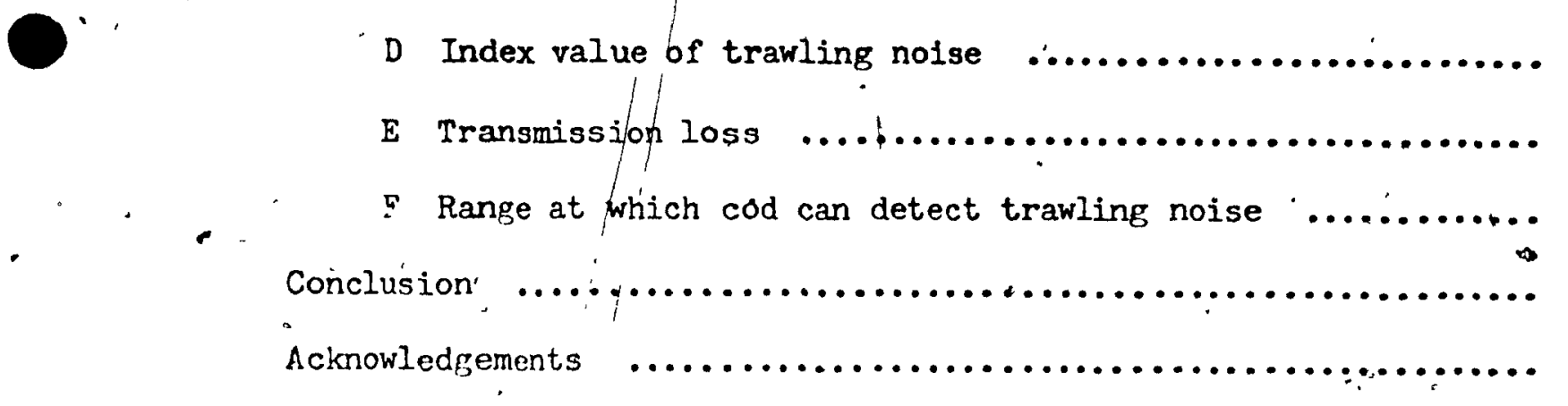

References

D Index value of trawling noise

E Transmission loss

I Range at which cod can detect trawling noise

Appendix

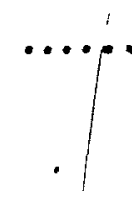

$\therefore$ 


\section{Introduction}

\section{All modem forms of commercial fish capture employ some knowledge} of fish behaviour. The essential information of where and when fish can be found, together with some exploitation of fish responses to stimuli form the basis for the capture process. To a great extent the information used in commercial fishing has accumulated through the generations of development of fishing methods by trial'and error. This approach has obviously resulted in many productive catching methods, but the underlying principles of fish behaviour, particularly responses to stimuli were not always understood. As economic pressures made it increasingly advantageous to continue the development of fishing gear and methods on a more scientific basis, this lack of understanding has been brought to attention.

Noise produced by fishing gear, or by the fishing operation, has only recently been recognized as a stimulus for fish reactions to fishing. Shortly after echo-sounders were first used in fish finding the question of whether fish were scared by sounder noise was discussed by Schubert (1950), and by Schärfe (1951). These authors conclude that there is no evidence of pelagic herring reacting to sounder noise, but both remarked that noises in the audible frequency range were known to produce scaring effects in these fish. The differentiation between sounder noise and noise in the audible frequency range, however, is misleading. Sounder noise consists of short pulses of frequencies that may themselves be too high to hear, but the spread of energy due to the pulsing makes the pulses quite audible to man and perhaps to fish' also.

In pelagic trawling, noise has been described as a stimulus for avoidance maneuvers of herring and other species by Aslanova (1958) and by Schärfe (1959). The usual reaction seems to be a dive to deeper water. 
Habituation to' continuing noise was also described.

More recentily scaring effects of noise on tuna, herring and other species have been described in purse seining (Chapman, 1970; Iversen, 1967; Maniva, 1970;01sen, 1970, 1971). Noise measurements of a. seiner that was making poor catches compared to other seiners (Hawkins and Chapman, 1969) showed it to be noisier than average at some frequencies but not pronouncedly so. The scaring effects described in the above reports are attributed not so much to steady ship noise as to changes in noise caused by changes in propeller speed and pitch.

It is clearly established that noise is a stimulus for avoidance maneuvers of fish in pelagic fisheries. In fișeries for groundfish, particularly bottom-trawling, there seems to be no.clear evidence of avoidance maneuvers or reactions to noise, despite investigations and discussions of both aspects in the literature.

The difference in our understanding of responses to fishing between pelagic fish and groundfish can be attributed to the difficulty of detecting fish on or near the bottom with echo-sounders. As v. Brandt (1959) pointed out, in pelagic trawling it is necessary to see fish traces on the echo-sounder before the gear can be set with any hope of making catches. In bottom-trawling on the other hand one can hope for catches, even without fish signs on the sounder. Pelagic trawling therefore provides a better opportunity to observe fish reactions incidental to fishing than does bottom-trawling.

The attemot by Schärfe (1956) to observe fish behaviour in relation to the bottom-trawl with an echo-sounder in a rubber boat above the trawl was unsuccessful. The noise produced by the groundrope caused interference on the echo-sounder. He concluded that conventional echo-sounders $\checkmark$ 
could not be used for these'studies. The level of noise produced by the groundrope was not measured, but was thought to be as loud as ship noise. Because the trawl was a conventional design, and catches of cod and haddock were normal, Scharfe concludes that the noise caused no, or at least no remarkable, flight responses.

To observe froundfish reactions to bottom trawling and to determine the relevant stimuli is obviously a problem that requires special effort and equipment.

Comparative fishing with different modifications of trawls can produce some understanding of fish responses to trawling. Bagenal (1958) compared catches made by otter trawls with catches made by a modification that had bridles between the doors and the wings. He suggested that the larger catches made with the modified trawl were likely due to the vibration of these bridles. To make more positive statements about fish beháviour from the results of comparative fishing would require analysis of the differences in stimuli produced by the modifications as well as the differences in catch.

Diving techniques have been used to observe groundfish behawiour in relation to capture. Hemmings (1967) used free diving to observe fish behaviour in response to the Danish seine. Korotkov (1969) and Martyshevskii et al. (1968) used a diving plane near bottom trawls: 11 three reports describe a herding of fish in front of the net, suggest that vision is the stimulus: Martyshevskii et al. go on to state that when fish cannot see the gear, particularly the cloud of turbulence stirred up by the otter boards, the stimulus might be noise.

Lagunov (1955) used a diving chamber suspended from a ship to observe fish and trawls. He saw no response to propeller and engine noise 

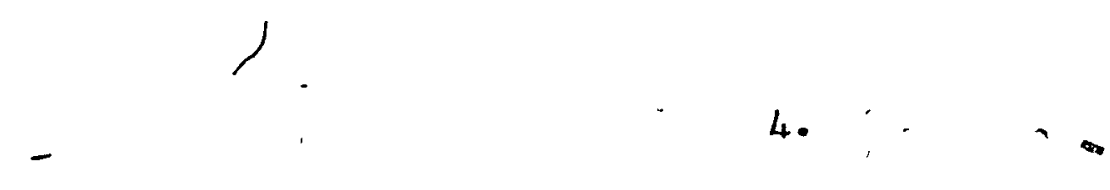

from the ship in cod and haddock. Similar observations were made by Kiselev (1968) who also used a diving chamber. He noted no responses of cod and haddock to noises made by passing vessels. He did note that in areas where many trawlers were operating the sea floor was stirred up, and cod seemed in a state of agitation. To clarify whether the agitation was due to the turbidity or due to the trawling noise he played back recorded trawling noise. In response, swimming cod became agitated during the first few moments and switched direction of swimming. Repetition of the sounds produced no responses. This suggests a startle response and rapid habituation. It does not clarify whether noises or the turbidity is the stimulus for the observed aglated state of the cod.

A camera attached to the headline of the trawl was used by Parrish et al. (1962). The camera was used in light and dark conditions. There was less uniformity of orientation with the tow of herrang and gadoids during dark than during light. Sand eels sometimes oriented with the tow even in the dark. Beamish (1966) also used a headline camera during day and night tows. During the night tows, orientation with the tow was less uniform than during day for both cod and haddock, but most haddock swam with the tow even at night. These results suggest that in visual range and in visual conditions, vision is the stimulus used by fish in their reactions to trawling. But the reports also show that some species can orient with the tow even in the dark.

Although there are no clear indications of groundfish reactions int. to trawling noise among reported observations, the suggestion that noise could sometimes be a stimulus appears repeatedly. This is no doubt due to the knowledge that trawling generates loud noises, that fish have ind sensitive hearing, and that noịse is a stimulus for pelagic species. 
Among groundfish species, hearing has been studied most frequently in cod. Buerkle (1967) used a change in cardiac rhythm as a conditioned response to sound stimuli to determine hearing thresholds of cod in a tank. The thresholds indicated that cod had sensitive hearing at low frequencies (below $400 \mathrm{~Hz}$ ) and that the sensitivity in this experiment was limited by the báckground noise in the experimental tank. Olser. (1967) also used condictioning experimentis to determine thresholds of cod in a tank. He reported sensitivities that were generally less than those reported by Buerkle (1967) but did not mention any effect of background noise.

The influence of varying levels of background noise on cod . hearing thresholdș was investigatgd by Buerkle (1968). Using the same conditioning technique as previously, he determined thresholds at five frequencies in four levels of background noise. The noise in this case was produced electronically in the octave band centered at the relevant signal frequency. The results indicated that thresholds varied directly with noise level and should be measured in terms of threshold to noise ratios. Another study using cardiac rhythm (Buerkle, 1969) investigated the effect of noise on thresholds in terms of the frequency separation between the noise and the signal at wich thresholds vere determined. To do this, the apparatus was set up so that the noise and the signal could be produced in any one of five half octave frequency bands. Thresholds were determined in all five signal bands for a constant noise level of $10 \mathrm{db}$ re $1 \mu$ bar in each of the, five noise bands. Three cod were tested with each noise bend, and each cod was used oniy' with one noise band. . Re'sults from the 15 cod tested showed that the masking of signal by noise was most pronounced when signal and noise coincided in frequency, and dropped off as the frequency separation between signal and noise . 
6.

increased. Masking was calculated in terms of threshold in relation to noise level and varied from about $11 \mathrm{db}$ when signal and noise were at the same frequéncy to about $-19 \mathrm{db}$ when'they were furthest removed from each other (separation of about $147 \mathrm{~Hz}$ ).

The measurements above were made in tanks and might reflect the acoustic characteristics of the tanks as well as the hearing capacities. of cod (Freytag, 1967). However, the few measurements of cod hearing that ,were made in open water in quiet fjords (Hawkins et al. 1969, Olsen, 1969) showed threshold to noise ratios that were quite similar to those determined in tanks. All the reports on hearing in cod support the tonclusion that they have sensitive hearing that is probably limited by ocean ambient noise.

A trawling noise spectrum was measured by Chapman et al. (1967). They compared the noise with thresholds of the lythe and concluded that trawling noise can be heard by marine fish "perhaps over conslderable distances." In another report (Chapman, 1970) the distance at which ship noise can be heard by fish is estimated at five miles. Olsen (1967) compared thresholds of cod to ship noise spectra and concluded that cod could hear the ship noise "at distances up to at least 70-80 meters".

The transmission loss used in making these estimates is the theoretical "20 log range" due to spherical spreading as described in Urick (1967). In transmission to distances several times the water depth, as it would occur when a fish 'hears' a trawler several miles away, propagation occurs by repeated reflections from the surface and the bottom. Spherical spreading is limited by these boundaries, and the acoustic characteristics of the boundaries are important determinants of the sound field. Application of the spherical spreading value is not strictly valid.

The present project was undertaken to determine more precisely at 


\section{7.}

what distances tod can detect trawling noise, and to determine which frequency components of the noise are most important.

\section{Experimental Procedure}

A. Recording of trawling noise

i) Procedure

J'

Previous measurements of trawling noise and of ship noise were made from recordings taken at relatively short ranges (Chapman et al., 1967; 01sen, 1967). In this investigation, noise from an approaching trawler was to be measured as it becomes audible to cod on the sea bottom. To make the recordings, the hydrophone was placed on the bottom from an anchored recarding boat. The recording boat was allowed to swing with the wind and tide on its anchor line, the slack hydrophone cable was to prevent the hydrophone from dragging over the bottom. For each recording, ambient sea noise was recorded for 10 to 15 minutes while the trawler stood by with engines off at about one mile $(1.8 \mathrm{~km}$ ) distance (all measurements in miles refer to nautical miles). The trawler then started the engines, set the trawl, and towed towards and past the hydrophone while the recording continued. The trawler passed the recording boat as close as possible without risking damage to the hydrophone by the trawl, or catching the anchor of the recording boat. When the trawl was thought to have passed the hydrophone, the tow and the recording were stopped. A voice track on the tape recorder was used to recard information on amplifier settings, wind, waves, and trawler operation. Earphones were used to monitor the recorded signals, and were essential in detecting disturbances caused by ship traffic and by the dragging 
8.

of the hydrophone or anchor.

ii) Recording site

Recordings were made in eastern Passamaquoddy Bay where mean water depth was approximately 60-70 feet (18-21 m) and average lowest low water depth was approximately 50-60 feet (15-18 m). The recording area was chosen to allow tows to be made towards the hydrophone over relatively smooth, flat bottom from a distance of ong mile $(1.8 \mathrm{~km})$. The bottom consisted of soft, brown mud. Distance of the recording sites was estimated by eye to be between .25 and .5 miles $(.46$ and $.9 \mathrm{~km})$ from shore. Wind and wave conditions during recording did not vary greatly, most recordings were made in light winds and whitecapped waves of approximately one foot $(.3 \mathrm{~m})$ height.

iii) The trawler and the trawl

The trawler was the Pandalus II, a research vessel operated by the Department of the Environment (Fisheries and Marine Service) -Biological Station, St. Andrews, N. B. Details are given in Table 1.

Tne trawl was a 3/4-35 Yankee otter-trawl made of polyethylene. The groundrope was equipped with 6 -inch $(15 \mathrm{~cm})$ diameter rubber rollers.

iv) Equipment

The components of the recording and analysis apparatus and their interconnections are shown in Figure 1. The hydrophone system was manufactured by Clevite Corp. (Cleveland, Ohio). 'It consisted of a sensor type $\mathrm{CH}-13 \mathrm{G}(\mathrm{T})$, a preamplifier module type $\mathrm{CE}-10 \mathrm{H}$, a * housing type $\mathrm{CB}-31 \mathrm{~A}(\mathrm{~T})$, and $600 \mathrm{ft}(183 \mathrm{~m})$ of cable type CU-4A. The specified sensitivity of the sensor was -77 dbv re $1 \mu$ bar. The specified frequency response was flat $\pm 1 \mathrm{db}$ from $.38 \mathrm{~Hz}$ to 
9.

Table 1: Specifications of the trawler.

Ship

M. V. "Pandarus II" -

Length (overall) $50 \mathrm{ft}(15 \mathrm{~m})$

, Beam $14 \mathrm{ft}(4.3 \mathrm{~m})$.

Draught $\quad 6.5 \mathrm{ft} .(2 \mathrm{~m})$

Gross tonnage 28.9 tons

Engine Gardner Diesel, 4 cylinder, 76 hop. at 900 r.p.m.

Auxiliary

Lister 2 cylinder. 10 hop.

Propeller

Solid, 3 blades, $37 " \times 30 "(94 \mathrm{~cm} \times$ $76 \mathrm{~cm}$ ). run through nominal $2: 1$ reduction gear.

Operation Trawling is done at 800 to $850 \mathrm{r} . \mathrm{p} . \mathrm{m}$. at a speed of $3.0 \pm .5$ knots $(5.6 \pm .9 \mathrm{~km}$ per hr.

Construction wood 

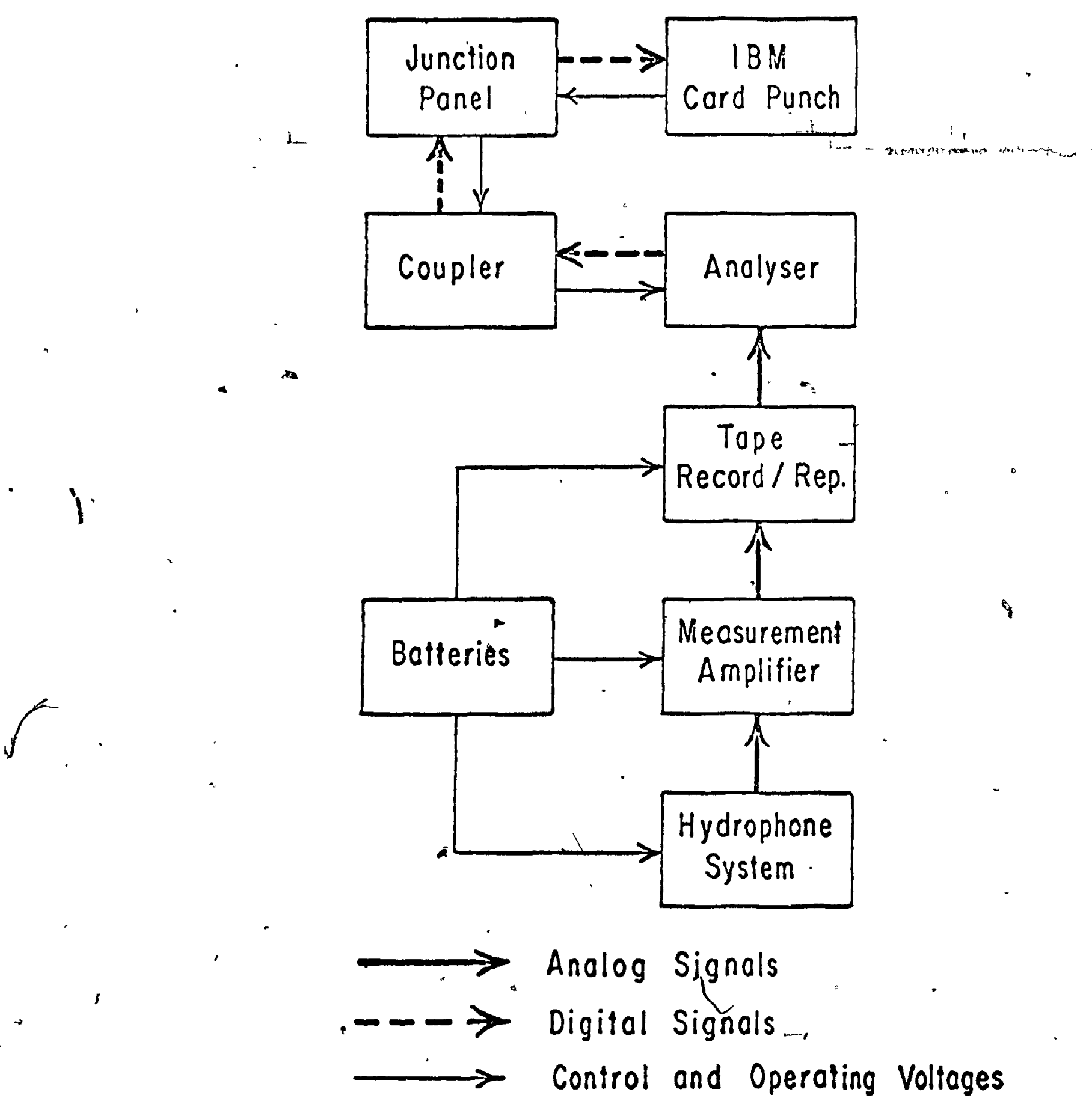

Figure 1. Block diagram of recording and analysis Instrumentation. 
11.

$11 \mathrm{kHz}$. The preamplifier module was calibrated to have a gain of $35 \mathrm{db}$ with the CU-4A cable, its frequency response was measured to be flat $\pm 3 \mathrm{db}$ from about $3 \mathrm{~Hz}$ to $20 \mathrm{kHz}$. At the low frequencies, response was down $10 \mathrm{db}$ at $1 \mathrm{~Hz}$. The system response was $-42 \mathrm{dbv}$, re $l \mu$ bar with the frequency response of the preamplifier. This' system was used for recordings made before January 15, 1971. It was extremely sensitive to overloads by low frequency pressure fluctuations caused by surface waves. To reduce this difficulty it was recommended by Clevite Corp. engineers, to reduce the sensitivity of this system by shunting the sensor with a $330 \mathrm{pF}$ capacitance. This was done, the sensitivity was then $-52 \mathrm{dbv}$ re $1 \mu$ bar. The modified system was. used for recordings made after January 15, 1971. It seemed somewhat less sensitive to overloads, but the problem was not entirely solved. Correction for the new sensitivity was made during analysis. The output from the hydrophone system was connected to a calibrated instrumentation amplifier (Eastech Industries, Dartmouth, N. S., model -329). The gain of the amplifier could be switched in $10 \mathrm{db}$ steps from 0 to $80 \mathrm{db}$. Because of the large dynamic range of noise pressures that occurred between the beginning and the end of a tow, it was necessary to reduce the amplifier gain as the trawling ngise became louder, so that the signal remained compatible with the inpyt sensitivity of the tape recorder. The output of the amplifier (i.e. input to the tape recorder) was kept between 0 and $-20 \mathrm{db}$ re 1 volt. The changes in amplifier gain were recorded on the voice track so that corrections could be made at the appropriate times during analysis. The tape recorder/reproducer was a Iockheed model 417 using 1/2" $(1.27 \mathrm{~cm})$ tape. It had 2 direct tracks, 2 FM tracks and 


\section{2.}

a voice track. It was used at a tape speed of $33 / 4$ ips $(9.53 \mathrm{~cm}$ per sec.). At this speed the frequency response of, the direct system. was flat $\pm 3 \mathrm{db}$ from 100 to $12,500 \mathrm{~Hz}$, the frequency response of the FM system was flat $\pm .5 \mathrm{db}$ from 0 to $1,250 \mathrm{~Hz}$. In the direct system, signal to RMS noise ratio over the pass band of the recorder was $35 \mathrm{db}$. In the FM system, it was $37 \mathrm{db}$. Input sensitivity of the direct system was readjusted to $0 \mathrm{db}$ gain. Input sensitivity and output voltage of the FN system was 1 volt RMS for full carrier deflection $( \pm 40 \%)$. Recordings were made simultaneously in one direct and one FM track. During the recording, the input level was monitored on a meter on the recorder. Earphones were used to monitor the recording on the tape in the simultaneous record/reproduce mode.

v) Results

Ten recordings were made from July to October 1970 with a $20 \mathrm{ft}(6 \mathrm{~m})$ long wooden seine skiff as the recording boat. Eight. recordings were made during January 1971 with a $57 . \mathrm{ft}$ (17 m) long wooden trawler as the recording boat. Difficulties occurred during six tows and the recordings were discarded because they were not representative of normal conditions. Two were discarded because the hydrophone dragged over the sea bed. Two were discarded because the tows were not continued long enough for the trawl to pass the hydrophone. One was discarded because of interfering noise from ship traffic. One was discarded because it contained frequencies that, for undiscovered reasons, did not show the characteristic rise in pressure as the trawler approached.

of the twelve recordings remaining for analysis, six were made during sumer (July to October 1970), and six were made in 
winter (January 1971).

B. Data processing

i) Aim

To determine at what frequencies and at what distance trawling noise becomes detectable to cod, the change in noise level, at different frequencies, "with time was to be measured over the whole length of each recording. The upper frequency limit of sensitive hearing in cod is about $300 \mathrm{~Hz}$. The FM track recordings were therefore analysed in $1 / 3$ octave bands using a real-time spectrum analyser. ii) Equipment

The recordings were reproduced on the Lockheed mode1 417 recorder/reproducer previously described. The output from the recorder/ reproducer was coupled to a Hewlett Packard (HP) model $8054 \mathrm{~A}$ Real Time Spectrum Analyser (Figure 1). The analyser was coupled to an HP model $2547 \mathrm{~A}$ coupler which was coupled through an HP model $2780 \mathrm{~A}$ junction panel to an IBM 526 summary card punch.

The function of the system was to filter the output from the recorder/reproducer into $1 / 3$ octave bands, and to punch the band voltages on computer cards sequentially and continuously during the analysis.

The analyser filtered the analog voltage from the recorder/ reproducer into $24 \mathrm{I} / 3$ octave bands (Table 2). It stored the voltage of each band for sequential scanning and conversion to digital form. The output was in $\mathrm{db}$ re $1 \mu$ volt and was programmed on the coupler patch-board to consist of a 3 digit whole number in each band. The card punch was programmed by its control card and patch-board to punch 24 3-digit numbers in sequence in the first 72 columns of every 
14.

Table 2. The 1/3 octave bands, band widths and power ratios.

\begin{tabular}{lccc}
$\begin{array}{c}\text { Band } \\
\text { number }\end{array}$ & $\begin{array}{c}\text { Center } \\
\text { frequency } \\
(\mathrm{Hz})\end{array}$ & $\begin{array}{c}\text { Band } \\
\text { width(a) } \\
(\mathrm{Hz})\end{array}$ & $\begin{array}{c}\text { Power } \\
\text { ratio(b) } \\
\text { db }\end{array}$ \\
\hline 1 & 3.15 & .73 & -1.4 \\
2 & 4 & 1.92 & -.4 \\
3 & 5 & 1.45 & .6 \\
4 & 6.3 & 1.84 & 1.6 \\
5 & 8 & 2.30 & 2.6 \\
6 & 10 & 2.87 & 3.6 \\
7 & 12.5 & 3.66 & 4.6 \\
8 & 16 & 4.60 & 5.6 \\
9 & 20 & 5.75 & 6.6 \\
10 & 25 & 7.30 & 8.6 \\
11 & 31.5 & 9.20 & 9.6 \\
12 & 40 & 11.5 & 10.6 \\
13 & 50 & 14.5 & 11.6 \\
14 & 63 & 18.4 & 12.6 \\
15 & 80 & 23.0 & 13.6 \\
16 & 100 & 28.7 & 14.6 \\
17 & 125 & 36.6 & 15.6 \\
18 & 160 & 46.0 & 16.6 \\
19 & 200 & 57.5 & 17.6 \\
20 & 250 & 73.0 & 19.6 \\
21 & 315 & 92.0 & 20.6 \\
22 & 400 & 115 & 21.6 \\
23 & 500 & 145 & 1.6 \\
24 & 630 & & 15 \\
\hline
\end{tabular}

(a) band width $=.231$ center frequency (Albers 1965)

(b) power ratio $=10 \log \frac{\text { band width }}{\text { l. Hz band width }}$ (Albers 1965) 
card and to skip the remalning 8 columns. In synchronisation with the analyser it punched the 24 band levels making up one spectrum on one card, and started a new card for each new spectrum. The speed of the analysis was limited by the punching speed of the punch to 14 spectra per.minute. A measurement was thus made in each band every 4.3 seconds during the whole analysis.

\section{iii) Procedure}

Because the amplifier,gain was varied during the recordings, compensation for the gain shift's had to be made during the cardpunching operation. It was done by inserting a cue card among the cards punched wherever an amplifier gain shift was announced on the voice track. In subsequent analysis the cue cards programmed the computer to compensate for amplifier gain changes, and to convert the $d b$ re $I \mu$ volt output on the cards to $d b$ re $I \mu$ bar of sound pressure in the water. The cue card correction for different amplifier gains that were subtracted from the db re $1 \mu$ volt on the cards are given in Table 3. They are the sum of the amplifier gain, the hydrophone system sensitivity and the $120 \mathrm{db}$ conversion factor to change the $\mathrm{db}$ re 1 volt amplifier output to $\mathrm{db}$ re $I \mu$ volt analyser output.

During the process of converting the recordings to numbers on computer cards, the various control and synchronisation voltages between card punch, coupler and analyser had to be initiated in correct sequence. The sequence was worked out with Hewlett Packard engineers and was used In setting up the following procedure.

(1) Hook up analyser, coupler, junction panel and card punch' as outlined in the respective operation manuals.

(2) Connect the output of the recorder/reproducer to input $B$ on 
16.

Table 3. Calculation of cue card correction.

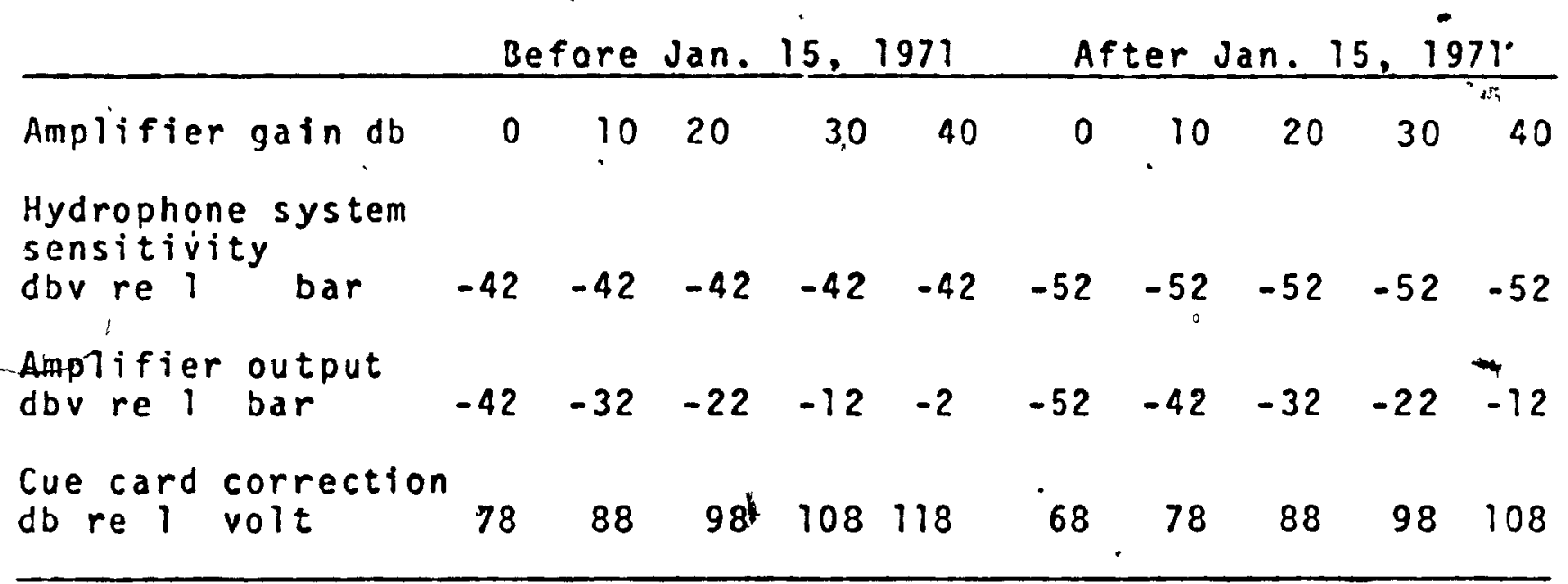

See text for explanation 
the analyser.

(3) Turn on power to all instruments.

(4) On the card punch:

- Put the control card on the drum, and the drum on the'spindle.

- Close control card contacts.

- Switch to automatic feed and automatic print.

1 - Ioad cards, release a card and address a card.

(5) On the coupler:

- Set REM.-IOC. switch to LOC.

- Set ON-OFF switch to OFF.

(6) Start recorder/reproducer on playback, and Iisten to the voice track with headphones for amplifier gain setting.

(7) Insert the appropriate amplifier gain cue card into the output hopper of the punch.

(\&) On the analyser:

- Push EXTERNAL INHIBIT button.

- Select sensitivity range to avoid overloads.

- Push RESET button.

(9) Rewind the tape on recorder/reproducer.

(10) Switch coupler REM.-LOC. to REM.

ON-OFF to ON.

(11) Start tape on playback.

(12) At "zero time" signal on voice track push EXT. INHIBIT button on analyser.

(13) Remove the first card that comes off card punch carriage.

(14) Check for correct synchronisation:

As the storage in the analyser is scanned, a bright trace 
moves from boy to band on the oscilloscope display "f the analyser. When synchronized correctly the bright trace hesitates on band 2 during a card change. If it hesitates 4 on any other band, synchronisation is not correct. To correct it, puşh RESET button and go back to step (9). (15) While cards are being punched, monitor the analyser for overloads and listen to the voice track continuously to the end of the recording.

- Whenever overloads occur, push RESET on analyser, stop tape, release card, switch analyser range higher, and start tape. When display is stable, push EXT. INHIBIT, and remove incomplete card as it comes off punch carriage. Check symchronisation (step 14 ).

- Whenever amplifier gain shifts are announced on the voice track, push RESET, stop tape, release card, insert appropriate amplifier gain cue card at bottom of output hopper of punch, and start tape. When the display is stable push EXT. INHIBIT : and remove incomplete card as it comes off the punch carriage. Check symchronisation (step $\mathcal{1}_{4}$ ).

iv) Results

During the punching of the cards, it was found that trawling i noise at close range contained over $40 \mathrm{db}$ more pressure at frequencies above $20 \mathrm{~Hz}$ than at frequencies below $25 \mathrm{~Hz}$. Since the dynamic range of the analyser at any one range setting was $40 \mathrm{db}$, it was necessary to punch 2 sets of cards for each recording. One set was punched with the analyser range adjusted so that frequency bands 1 to 9 (3.15 to $20 \mathrm{~Hz}$ ) were within the dynamic range of the analyser. The other set 
19.

was punched so that bands 10 to $21(25$ to $315 \mathrm{~Hz})$ were within the dynamic range of the analyser. Subsequent analysis for each frequency was done in the appropriate set of cards. The $24^{-}$sets of cards for : the 12 recordings under consideration contained a total of $13 ; 650$ cards.

C. Data analysis

i) Data reduction and smoothing.

Hearing in cod is insensitive to frequencies above about $300 \mathrm{~Hz}$ (Buerkle, 1967). For this reason, analysis was done in frequency bands 1 to $21(3.15$ to $315 \mathrm{~Hz})$ and not at higher frequencies. There were more than 143,000 3-digit numbers in these bands in the 12 recordings to be analysed. On the average, each frequencyl band was represented by approximately 570 measurexents.

To reduce and smooth the data, moving averages were caldted. Each average was the average of 14 measurements and represented a time period of 1 minute because the card punch produced $u_{4}$ spectra per minute. Succeding averages overlapped preceding averages by 7 measurements making a time difference of 30 seconds between averages (see Figure 2). This resulted in a mean of 80 averages in each frequency band in each recording, or a total of approximately 20,000 averages to be analysed. Examples of the change in averages with time are shown in 5 Figure 3. They show little change in level during the time that ambient ocean noise was measured pefore trawling started. When trawling started, the noiše levels in some bands began to rise and continued to rise as the trawler approached the hydrophone. Equations to describe mean trawling noise in relation to distance along the tow path were calculated and are drawn for the example in Figure 3.

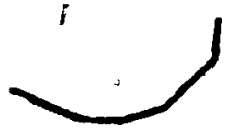


Measưrement Numbers

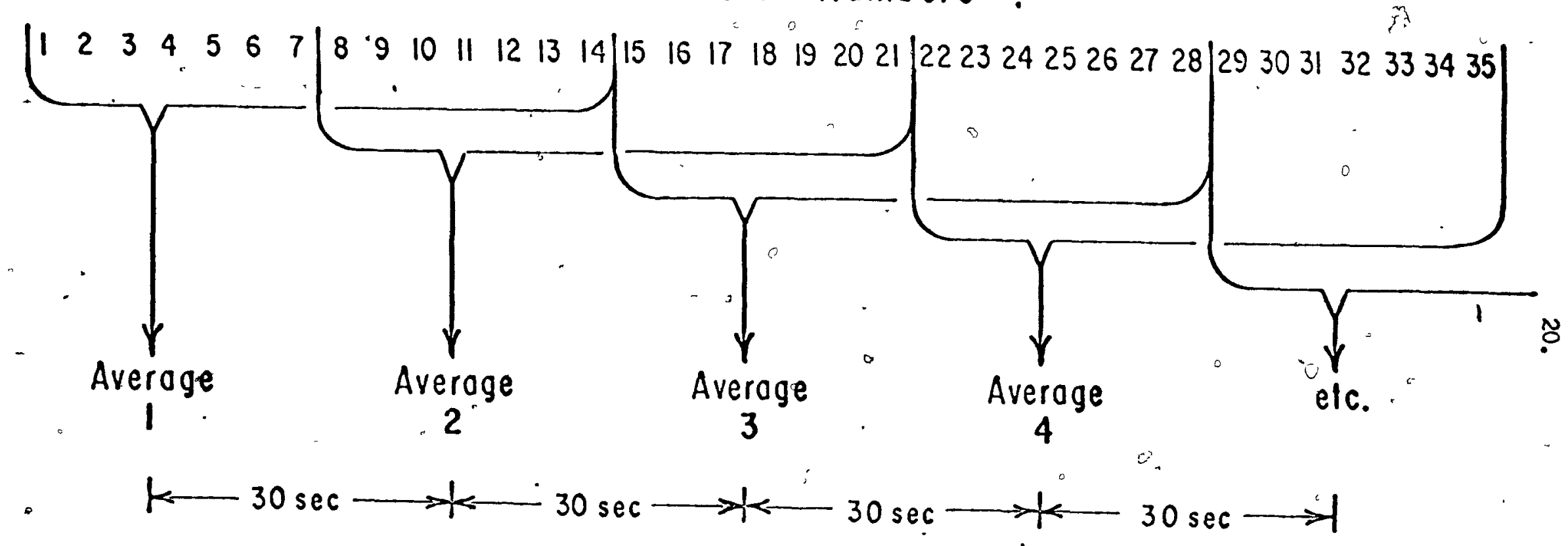
Figure. 2. Relationship between moving averages and measure-
ment numbers and time. 


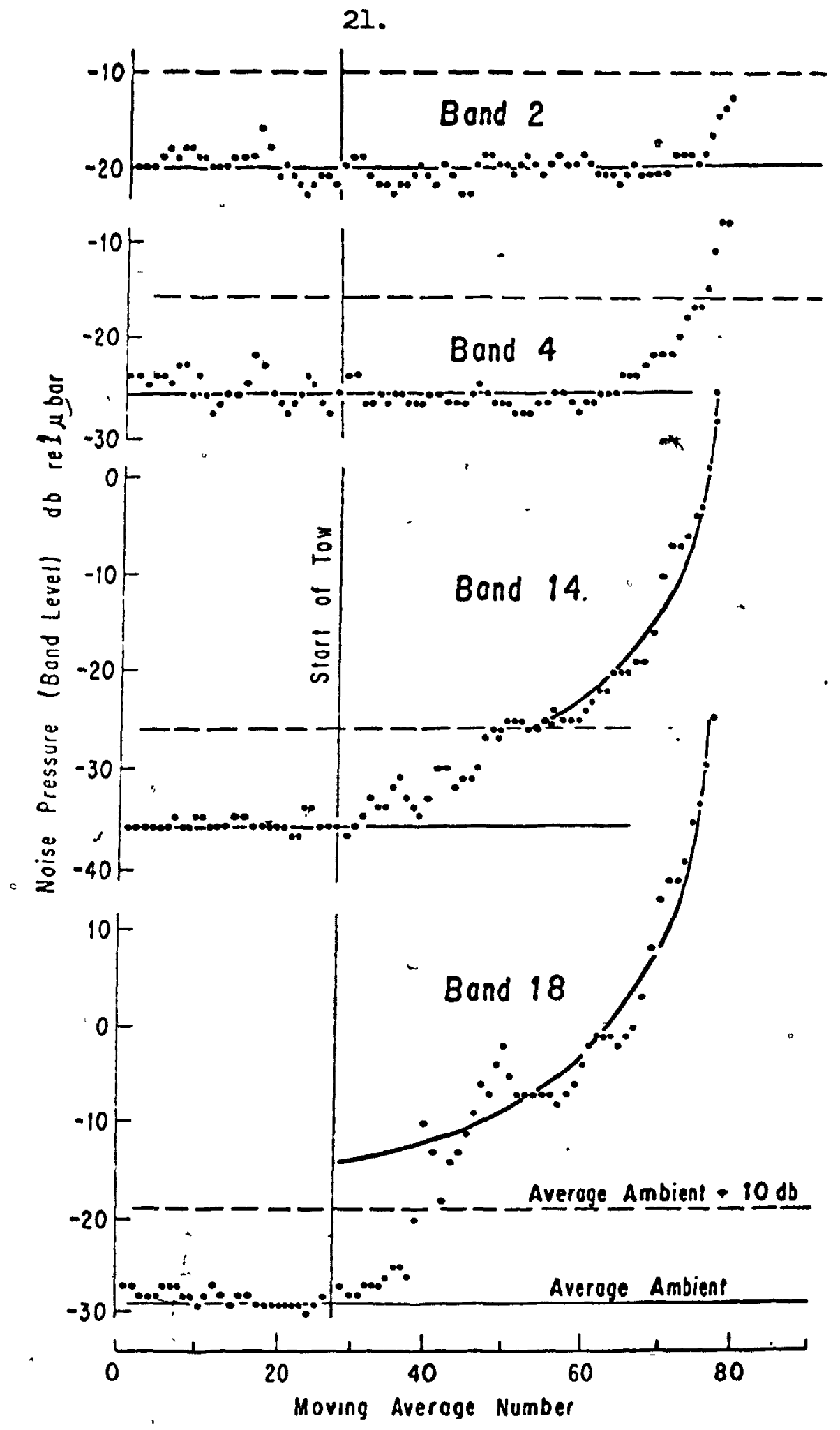

Figure 3. Hoving averages of 4 frequency bands (from recording 3, August 29,1970$)$.

Band 2. No averages above average ambient $+10 \mathrm{db}$ Band 4. 4 averages above average ambient $+10 \mathrm{db}$. no equation calculated.

8and 14. Equation calculated for 30 averages.

Band 18. Equation calculated for 38 averages. 
ii) Calculation of mean trawling noise in relation to distance along the tow path.

(a) Effect of ambient noise.

When measured trawling noise is less than $10 \mathrm{db}$ above ambient sea noise, the measurement is not of trawling noise alone but of the sum of trawling noise and ambient noise. When trawling noise is $10 \mathrm{db}$ or more above ambient noise, the ambient noise has no effect on the measurement of trawling noise (Albers, 19655, Appendix 3). Before equations were calculated, therefore, trawling noise measurements that were less than $10 \mathrm{db}$ above average ambient sea noise were eliminated. The average ambient sea noise of each band in each recording was calculated from the moving averages of measurements made before trawling began (Figure 3). The equation for any band was calculated from the averages that were $10 \mathrm{db}$ or more above the average ambient noise and that followed the last average below that level. No equation was calculated for bands that had less than 5 averages that met this criterion. 
23 .

radar to be $.75, .50, .25$ and 0 miles $(1.4, .9, .5$ and $0 \mathrm{~km})$. During the punching of the cards for these recordings, cue cards were inserted whenever the voice track indicated a distance. The number of data cards between the cue cards were later counted and used in the calculations in Table 4. The distances of $146 \mathrm{ft}(44 \mathrm{~m})$ and $13 \mathrm{lt}(40 \mathrm{~m})$ are the upper and lower $95 \%$ fiducial limits of the mean distance along the tow path between adjacent moving averages. They were used in each recording in every band with sufficient averages to calculate one equation with the maximum and one with the minimum intercept respectively. A total of 324 equations were calculated, their intercepts (A) and slopes (b) are listed by recording and band number in the Appendix. '

The two equations in each of the 162 bands of the Appendix describe mean maximum and mean minimum trawling noise relative to distance along the tow path in each band. They were used to calculate the maximum and minimum range at which trawling noise becomes detectable for cod in each of the bands. iii) Calculation of masking levels.

For cod to detect trawling noise at sea, their auditory . apparatus must be able to separate the tonal stimulation caused by the trawling noise from that caused by the ambient sea noise. That is, the trawling noise must not be masked by ambient sea noise.

To determine the masking level, the level at which ambient noise masks trawling noise, in each frequency band of each recording, the measurements of auditory masking in cod made Buerkle (1969) were used. Figure 4 reproduces Figure 2 from Buerkle (1969). It shows the 
0

24.

Table 4. Calculation of towing speed and of distance between moving averages.

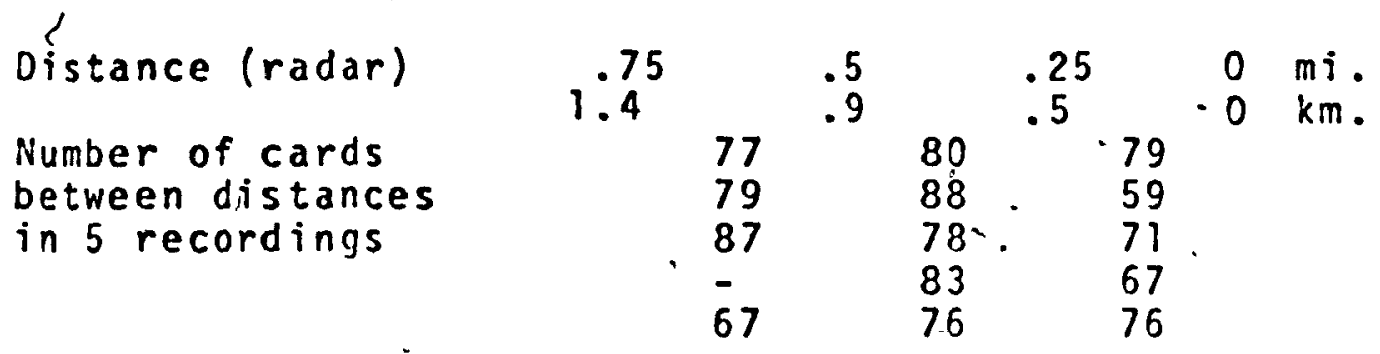

Mean number of cards per $1 / 4$ mile $=76.2$ Standard error of the mean $=2.1$

$95 \%$ fiducial $=321.6$ to 288.0 cards per mile interval limits

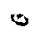

$$
\begin{aligned}
= & 131 \text { to } 146 \text { feet per aver } \\
& (40 \mathrm{~m})(44 \mathrm{~m}) \\
\text { towing speed }= & 2.6 \text { to } 2.9 \mathrm{knots}^{+} \\
& (4.8 \text { to } 5.4 \mathrm{~km} \text { per } \mathrm{hr})
\end{aligned}
$$

$$
\begin{aligned}
& \text { * feet per average }=\frac{\text { feet per nautical mile }}{\text { cards per mile }} \times 7 \\
& + \\
& + \text { knots }=\frac{\text { cards per hour }(=840)}{\text { cards per mile }}
\end{aligned}
$$


25.

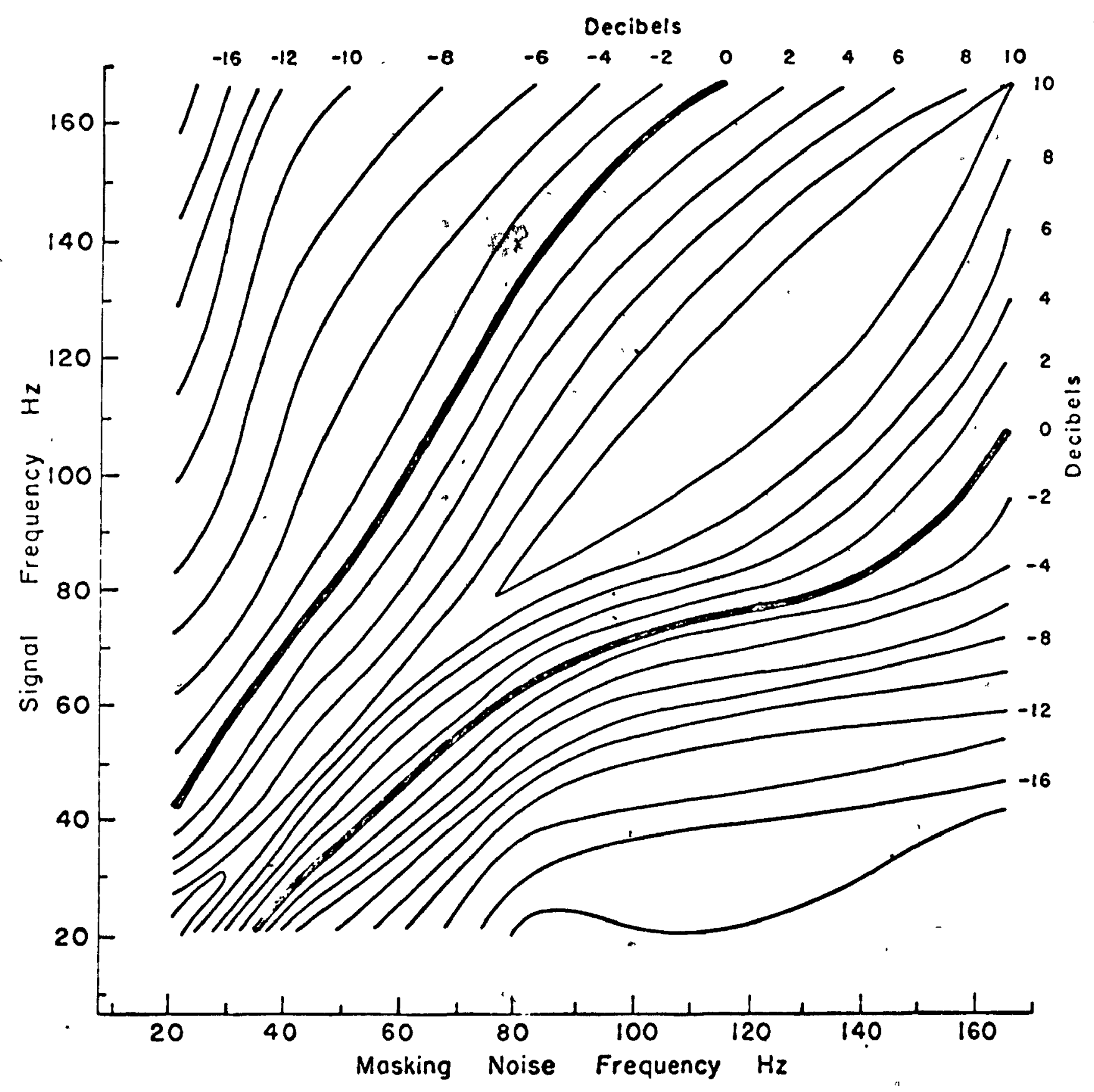

Figure 4. Contour plot of masking in decibels of signal threshold in relation to masking noise level (Fig. 2 in Buerkle 1969). 
26.

relationship, by signal. frequencies and noise frequencies, of thresholds and masking noise in decibels. To determine the slopes by which threshold re masking noise decrease with increased separation between signal

frequency and masking frequency, the values of Table 5 were interpolated from Figure 4. For each noise frequency, two regressions of threshold

- re masking noise versus signal frequency were calculated, one for signal frequencies higher than the noise frequency, the other for signal frequencies lower than the noise frequency. The slopes of edch regression, and the mean slope for signal frequencies higher than noise frequency and for signal frequencies lower than noise frequency are shown in Table 6 .

The masking level of each frequency band was calculated from the mean slopes and from the average ambient noise level in each recording. For every signal band, the frequency of each of the 21 noise bands was subtracted from the frequency of the signal band. Positive sums were multiplied by $-.2 \mathrm{db}$ per $\mathrm{Hz}$, negative sums were multiplied by $-.4 \mathrm{db}$ per $\mathrm{Hz}$. Because signals at the same frequencies as masking noise are detected only when they are a minimum of $10 \mathrm{db}$ above the masking noise (Figure 4 and Table 5), the product for each noise band was added to the average ambient noise $+10 \mathrm{db}$ level of the noise band. The maximum of the 21 sums obtained for each signal band was the pasking level of that. band. The masking levels for the 162 bands in the Appendix are listed there under "Masking level".

iv) Calculation of range at which cod can detect trawling noise.

A distance $D$ at which trawling noise equals masking level can be calculated from each intercept (A), slope (b), and masking level $\$$ (Mil) of the Appendix. By substituting masking level for decibels in the 
27.

Table 5. Cod thresholds relative to masking noise level in decibels (interpolated from Fig. 4).

Noise frequency

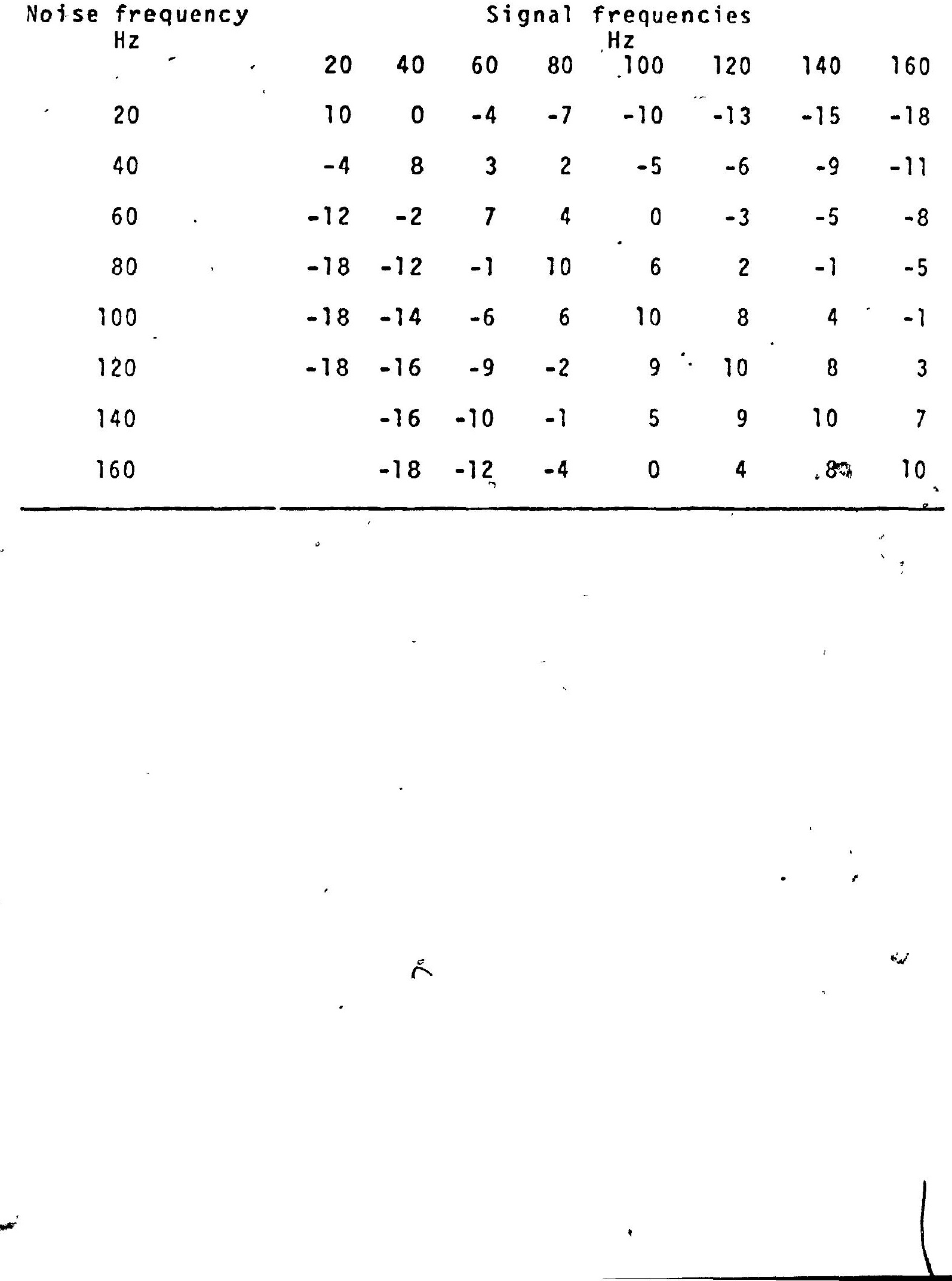


28.

Table 6. Slopes of threshold or masking noise for signal frequencies higher than noise frequencies, and for signal frequencies lower than noise frequency.

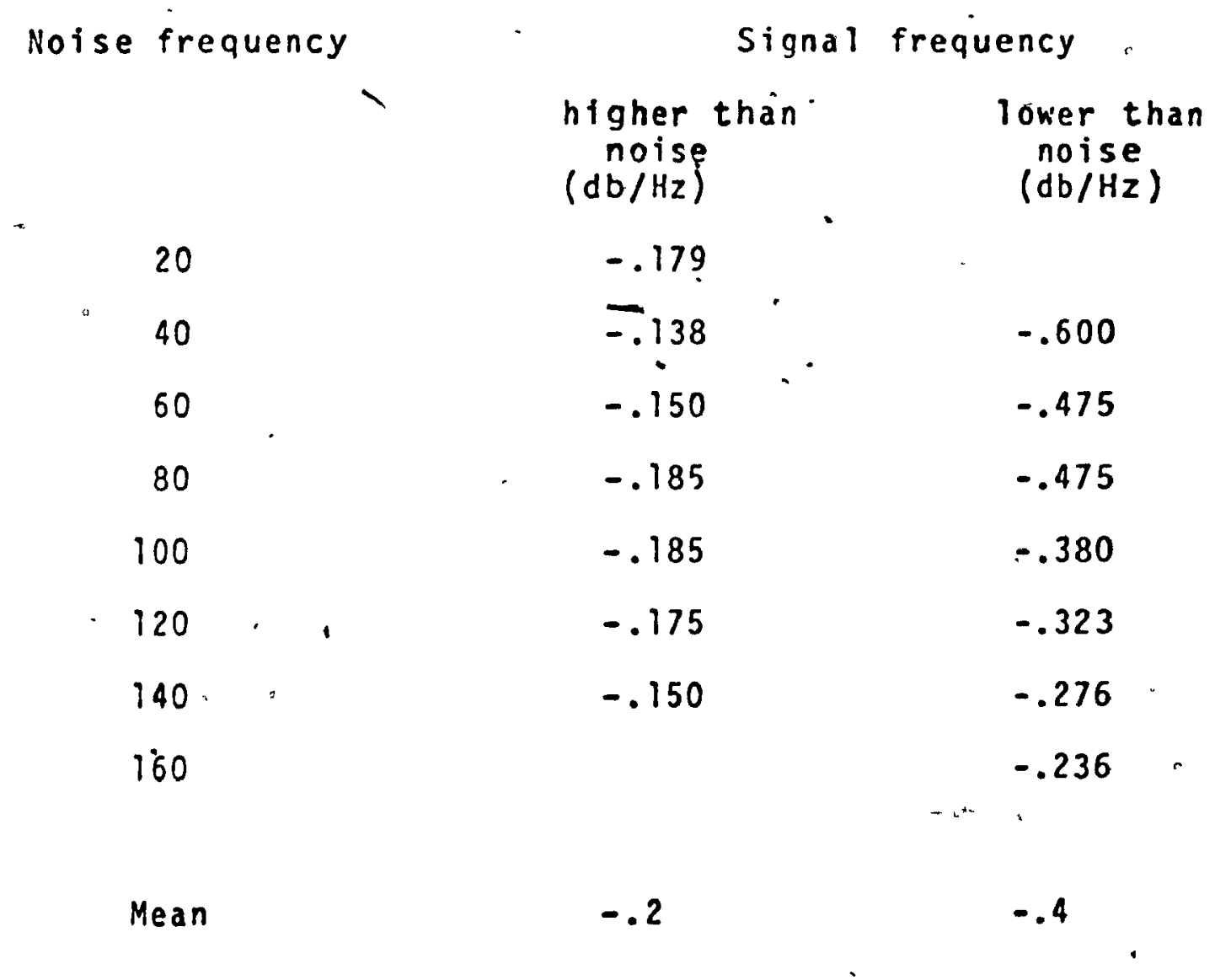


29.

general equation $d b=A+b \log \frac{D}{\text { Dreff. }}$, the equation becomes $\mathrm{MC}=$ $A+b \log D$ and $D=\operatorname{ant1} \log \frac{M-A}{b}$, when Dreff. $=1$. The D represents the distance back along the tow path from the intercept of the equation to where trawling noise equals masking level. At shorter distances, trawling noise is above the masking level, at longer distances it is below the masking level. The intercept of the equations, however, is a theoretical point at distance $=0$, and does not represent the point at which the noise source was actually closest to the hydrophone. To correct for this, the closest point along the tow path between the noise source and the hydrophone was determined as follows.

As naise sources move along the tow path towards the hydrophone and pass it, the noise levels at the hydrophone should rise to a peak as the distance between the source and the hydrophone becomes minimum. The peak represents the closest point along the tow path between the noise source and the hydrophone. The peak moving average in each of the 162 bands in the Appendix was determined. For a number of bands the loudest moving average was also the last moving average of the series (Figure 3). In such cases, the loudest moving average cannot properly be called a peak. Examination of the measurements from which the moving averages were calculated, however, revealed that in all these cases included in this report the measurements did rise to a peak and decrease again. Therefore, when the loudest moving average was the last of the series, there were simply not enough decreasing measurements to lower the average below the previous one, but the loudest average does represent the peak noise' pressure.

The distance (d) between the peak moving average and the intercept of each equation was calculated from the number of distance increments 
30.

between them and the relevant increment size of $146 \mathrm{ft}(4 \mathrm{4m})$ or $13 i \mathrm{ft}$ $(40 \mathrm{~m})$. These distances (d) are shown in the Appendix in feet.

The range $(r)$ along the tow path between the closest point to the hydrophone and the masking level was then $r=D-d$ or, $r=$ antilog $\frac{\mathrm{ML}-\mathrm{A}}{\mathrm{b}}-\mathrm{d}$. The $\mathrm{r}$ is always greater for the equation based on the $146 \mathrm{ft}(44 \mathrm{~m})$ increments than for the equation based on the 131 $\mathrm{ft}(40 \mathrm{~m})$ increments. The range $r$, however, is still not the range at which cod can detect trawling noise because the hydrophone and thus the hypothetical cod were not located on the tow path. Figure 5 illustrates the geometry of the recording situation. As described previously, the recording boat swung on its anchor line and excess hydrophone cable was used to prevent the hydrophone from dragging over the sea floor. This permitted the hydrophone to be located anywhere within a radius of several hundred feet of the recording boat. The tow paths were straight lines that passed the recording boat at distances with a maximum of about $300 \mathrm{ft}(90 \mathrm{~m})$. Because the minimum water depth was about $5 \mathrm{q} \mathrm{ft}(15 \mathrm{~m})$, this meant that a noise source moving along the tow path at the surface could be anywhere from about $50 \mathrm{ft}(15 \mathrm{~m})$ to about $500 \mathrm{ft}(150 \mathrm{~m})$ from the hydrophone at the closest point (Figure 5).

To calculate the maximum and minimum range $(R)$ at which cod can detect trawling noise, this distance between the hydrophone and the closest point hagd to be corrected for. Figure 6 illustrates the relationship between $R, r$, and the hydrophone distance from the closest point. As described previously, each of the 162 bands in the Appendix has a maximum and a minimum $r$. It can be seen in Figure 6 that the maximum and minimum $R(f t)$ in each band will be $\left(r \max .^{2}+500^{2}\right)^{1 / 2}$ and $\left(r \min .{ }^{2}+50^{2}\right)^{1 / 2}$ respectively. The maximum and minimum range $R$ 


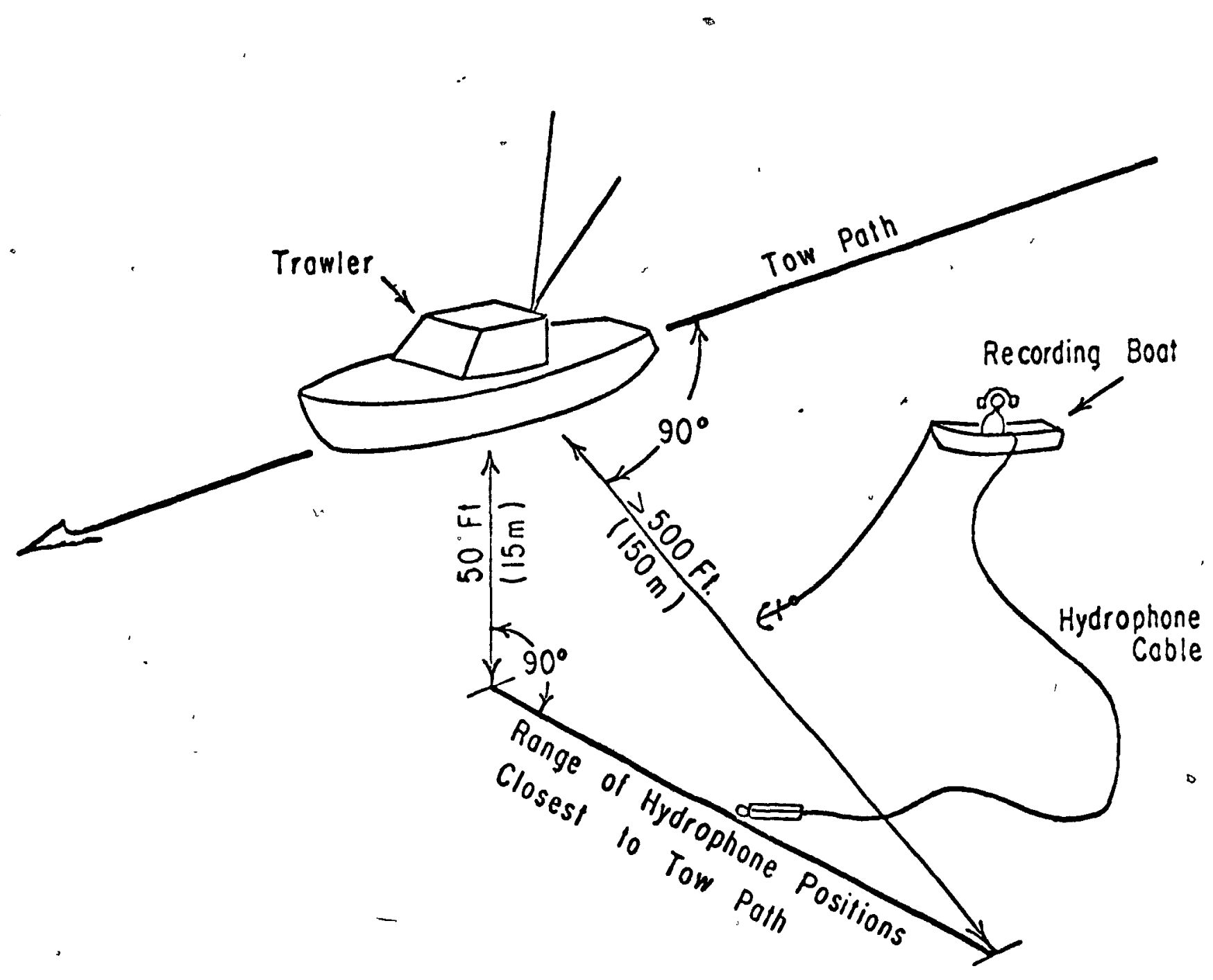

Figure 5. Recording geometry. 
33.

in feet at which cod can detect trawling noise in each band of each recording is listed in the Appendix.

Results and Discussion 0

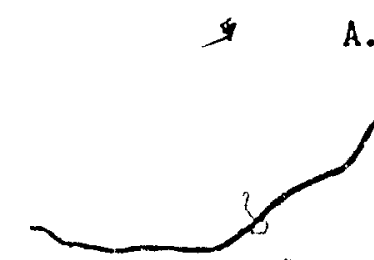

A. Ambient sea noise

Table 7 shows the band level of average ambient sea noise in each band for each of the 6 surmer recordings and for each of the 6 winter recordings. The mean in each band and its $90 \%$ fiducial limits is calculated for the surmer recordings and the winter recordings and is shown' as spectrum level (spectrum level = band level - power factor of Table 2). The mean spectrum levels and their $90 \%$ fiducial limits are illustrated on a logarithmic frequency scale in Figure 7.

The differences between the summer and winter mean noise levels were significant at the $90 \%$ level (' $t$ ' test) in all frequency bands except bands 4,5 and 6 . Higher noise levels in winter were also reported by Piggott (1964) for shallow waters of the Scotian Shelf. He attributes the higher noise levels in winter to the difference in vertical sound velocity profile, The vertical sound velocity profile is defined as the variation of sound velocity with depth (Urick, 1967). A positive vertical velocity profile means that sound velocity increases with depth and a negative vertical velocity profile means that the sound velocity decreases with increased 'depth. On the Scotian Shelf, the vertical velocity profile in winter is positive, and attenuation coefficients are. smaller than in surmer when the vertical velocity profile is negative (Piggott, 1964): Measurements of velocity profiles in Passamaquoddy Bay have not been reported, the temperature structure, however, is warmer at the surface in summer and warmer near the bottom in winter while salinity is always higher near the bottom (Forgeron, 1959). Since 
34.

Table 7. Average amblent noise in db re $1 \mu$ bar.

Average ambient noise (band levels) summer recordinas

Band

$\begin{array}{llllllllll}1 & -21 & -12 & -14 & -16 & -18 & -24 & -19.1 & -16.1 & -13.1 \\ 2 & -28 & -15 & -20 & -21 & -21 & -23 & -23.8 & -20.9 & -18.1 \\ 3 & -31 & -19 & -23 & -22 & -23 & -23 & -26.8 & -24.1 & -21.4 \\ 4 & -32 & -20 & -24 & -20 & -24 & -22 & -28.2 & -25.3 & -22.3 \\ 5 & -28 & -24 & -23 & -24 & -25 & -22 & -28.3 & -26.9 & -25.6 \\ 6 & -27 & -24 & -24 & -26 & -24 & -23 & -29.3 & -28.3 & -27.3 \\ 7 & -25 & -25 & -28 & -28 & -25 & -24 & -31.6 & -30.4 & -29.3 \\ 8 & -23 & -28 & -29 & -31 & -29 & -26 & -35.1 & -33.3 & -31.4 \\ 9 & -29 & -32 & -31 & -35 & -32 & -30 & -39.5 & -38.1 & -36.7 \\ 10 & -35 & -35 & -33 & -35 & -34 & -32 & -42.4 & -41.6 & -40.8 \\ 11 & -39 & -36 & -33 & -35 & -35 & -34 & -45.3 & -43.9 & -42.6 \\ 12 & -37 & -34 & -31 & -33 & -35 & -33 & -44.8 & -43.4 & -42.1 \\ 13 & -34 & -31 & -32 & -33 & -36 & -32 & -44.8 & -43.6 & -42.4 \\ 14 & -35 & -29 & -30 & -30 & -36 & -30 & -45.3 & -43.3 & -41.3 \\ 15 & -34 & -29 & -31 & -29 & -36 & -29 & -45.9 & -43.9 & -41.9 \\ 16 & -32 & -28 & -30 & -27 & -35 & -29 & -45.7 & -43.8 & -41.8 \\ 17 & -35 & -28 & -30 & -24 & -33 & -29 & -47.0 & -44.4 & -41.8 \\ 18 & -37 & -28 & -29 & -22 & -29 & -30 & -48.0 & -44.8 & -41.6 \\ 19 & -35 & -29 & -28 & -20 & -27 & -33 & -48.8 & -45.3 & -41.8 \\ 20 & -33 & -27 & -25 & -17 & -23 & -35 & -48.7 & -44.3 & -39.8 \\ 21 & -30 & -25 & -23 & -15 & -21 & -35 & -48.1 & -43.4 & -38.7\end{array}$

- Mean and $90 \%$ fiducial limits (spectrum level)

winter recordings

$\begin{array}{rrrrrrrrrr}1 & -9 & -10 & -9 & -16 & -16 & -5 & -12.3 & -9.4 & -6.5 \\ 2 & -12 & -14 & -10 & -21 & -22 & -7 & -18.0 & -13.9 & -9.9 \\ 3 & -15 & -17 & -12 & -24 & -25 & -8 & -21.9 & -17.4 & -13.0 \\ 4 & -20 & -23 & -16 & -28 & -29 & -13 & -27.4 & -23.1 & -18.8 \\ 5 & -20 & -27 & -18 & -29 & -30 & -12 & -30.0 & -25.3 & -20.5 \\ 6 & -20 & -25 & -18 & -27 & -28 & -16 & -29.3 & -25.9 & -22.6 \\ 7 & -21 & -25 & -20 & -24 & -24 & -17 & -28.7 & -26.4 & -24.4 \\ 3 & -21 & -26 & -21 & -27 & -25 & -18 & -31.0 & -23.6 & -26.2 \\ 9 & -22 & -27 & -21 & -30 & -29 & -15 & -34.4 & -30.6 & -26.8 \\ 10 & -21 & -27 & -21 & -28 & -29 & -16 & -34.7 & -31.3 & -27.8 \\ 11 & -21 & -27 & -21 & -31 & -32 & -19 & -37.5 & -33.8 & -30.0 \\ 12 & -21 & -23 & -21 & -27 & -31 & -20 & -36.3 & -33.4 & -30.5 \\ 13 & -17 & -15 & -20 & -7 & -17 & -14 & -28.6 & -25.6 & -22.6 \\ 14 & -21 & -24 & -17 & -20 & -27 & -18 & -35.3 & -32.8 & -30.2 \\ 15 & -20 & -22 & -18 & -26 & -31 & -17 & -38.5 & -34.9 & -31.4 \\ 16 & -19 & -23 & -17 & -27 & -28 & -17 & -38.7 & -35.4 & -32.1 \\ 17 & -18 & -20 & -15 & -24 & -29 & -17 & -38.6 & -35.1 & -31.6 \\ 18 & -17 & -17 & -14 & -22 & -28 & -15 & -138.0 & -34.4 & -30.9 \\ 19 & -15 & -16 & -12 & -21 & -27 & -14 & -37.8 & -34.1 & -30.4 \\ 20 & -13 & -15 & -10 & -19 & -25 & -12 & -37.0 & -33.3 & -29.6 \\ 21 & -11 & -14 & -9 & -20 & -24 & -11 & -37.4 & -33.4 & -29.5\end{array}$




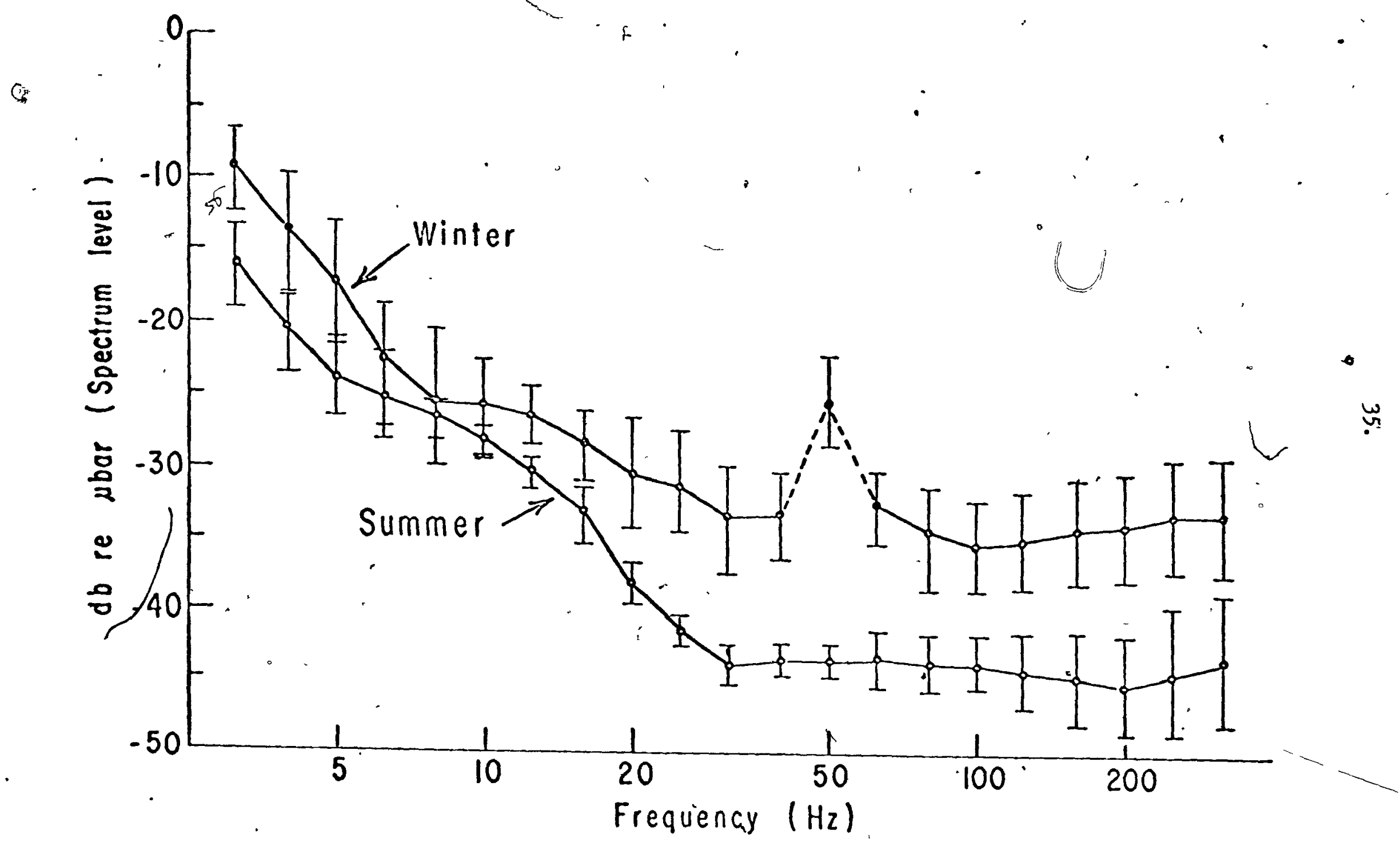

Figure 7. Mean ambient noise spectrum level. 


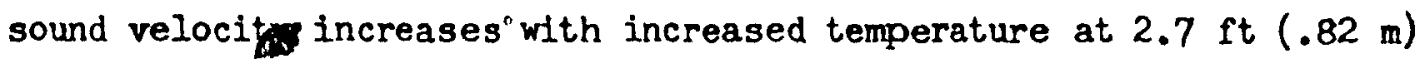
per second per ${ }^{\circ} \mathrm{C}$ and increases with increased salinity at $4 \mathrm{ft}(1.22 \mathrm{~m})$ per second per 1 ppt., a positive vertical sound velocity profile in winter is most certain and a negative vertical sound velocity profile in sumer is quite probable in Passamaouoddy Bay. This difference no doubt accounts for the difference between sumer and winter ambient noise. The peak in winter ambient noise in band $13(50 \mathrm{~Hz})$ is probably due to electrical interference produced by the recording boat. As described previously, 'winter recordings were made from a trawler. It had radio and radar equipment in operation during the recording. The equipment was operated so that the measurements of range between the trawler and the recording boat that were needed to estimate the towing speed could be made. Such equipment often emits electrical noise to which a tape recorder could be sensigtive.

Recordings were made during periods when the wave height was about $1 \mathrm{ft}(.3 \mathrm{~m})$ and there were white caps. Periods of calm surface were, not encountered, and when the waves were large, recordings could not be made because the recording boat then generated noise by slapping on the waves. The resulting small range of sea states during which recordings were made, does not permit comparison of ambient sea noise at different sea states. Pigott (1964) describes sea noise spectrum level on the Scotian Shelf in relation to wind speed. The combined sumer-winter average ambient noise spectrum level measured in this project corresponds approximately in level to the combined summer-winter average noise reported by Piggott at wind speeds of 6 to 9 miles per hour.

The measured ambient noise also fits well within the linits of prevailing noise described by Wenz (1962). Sources of noise described is 
37.

by Wenz that could contribute to the measured noise levels are: turbulent pressure Muctuations due to surface waves for frequencies 1 to $10 \mathrm{~Hz}$ "turbulent pressure fluctuations due to siesmic background for frequencies 1 to $100 \mathrm{~Hz}$, distant oceanic traffic for frequencies 12 to $315 \mathrm{~Hz}$, and bubbles and spray due to surface agitation for frequencies 100 to $200 \mathrm{~Hz}$. In addition, there could be intermittent sources such as ships, industrial activity, and biological sources. These, however, would not be major contributors to the noise described here because care was taken to record only when there were no known intermittent disturbances.

B. Masking

Auditory masking in cod was measured in the frequency range of 20 to $160 \mathrm{~Hz}$ (Buerkle, 1969). Ambient noise measured in this project was loudest at frequencies below $20 \mathrm{~Hz}$. The possible masking of trawling noise by these low frequencies can either be ignored because nothing definite is known about masking at frequencies below $20 \mathrm{~Hz}$, or it can be quantified by extrapolations of the published data on masking. The latter approach was chosen because it seemed unreasonable that the high noise levels below $20 \mathrm{~Hz}$ should have no masking effect.

To illustrate the masking effect, the mean masking for summer and winter recordings is described. Figure 8 shows the relationship of the spectrum levels of mean ambient noise $+10 \mathrm{db}$, mean masking levels, and the slope of masking of higher frequencies by lower frequencies. The mean masking levels were calculated from the previously described band level masking levels, the slope of the masking effect was also previously described as $-.2 \mathrm{db}$ (band level) per $\mathrm{Hz}$. Although the masking levels and the masking slope were previously described as band levels 


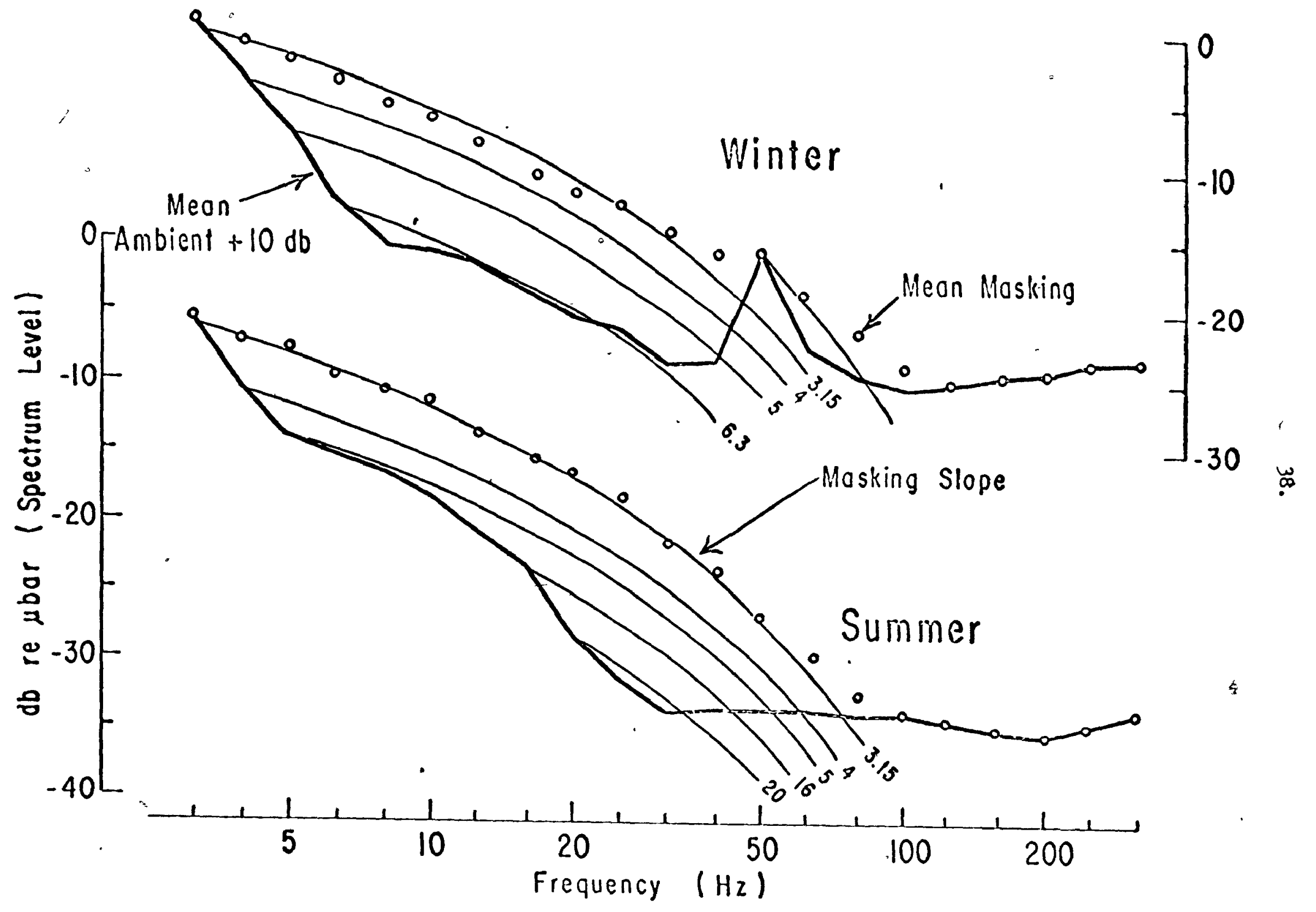

Figure 8. Relationship of mean ambient noise $+10 \mathrm{db}$, mean masking levels and slope/of masking of higher frequencies by fower fhequencies. 
39.

and were used as such in the calculation of the range (R), Figure 8 shows the relationship in terms of spectrum level because the mean ambient noise was previously described as spectrum level. The conversion does not affect the relationships.

The masking effect of low frequencies is illustrated by the family of curves of masking slope originating at some of the low frequencies. For example, the curve marked 3.15 is the level at which the mean ambient noise at $3.15 \mathrm{~Hz}$ masks higher frequencies, and the curve marked 4 is the level at which the mean ambient noise at $4 \mathrm{~Hz}$ masks higher frequencies. It can be appreciated that the mean masking level at any frequency in summer or winter, is the mean of the highest masking effect in eactipf the 6 relevant recordings.

In winter, the mean ambient noise between 3.15 and $4 \mathrm{~Hz}$ masks frequencies up to about $40 \mathrm{~Hz}$. Then the peak of noise at $50 \mathrm{~Hz}$, previously described as electrical interference, masks a few frequencies above and below $50 \mathrm{~Hz}$. From about $100 \mathrm{~Hz}$ up, each frequency is masked only by noise of the same frequency. In summer, noise at $3.15 \mathrm{~Hz}$ masks frequencies up to about $80 \mathrm{hz}$. Since there was no electrical interference at $50 \mathrm{~Hz}$, this is probably the correct situation for winter also. As in winter, frequencies above about $100 \mathrm{~Hz}$ are masked only by noise of the same frequency.

Figure 8 also' shows that should the low frequency masking not occur, and all frequencies are masked only by noise of the same frequency, masking levels of frequencies between 3.15 and $100 \mathrm{~Hz}$ would on the average be about $7 \mathrm{db}$ lower. At $25 \mathrm{~Hz}$ the difference would be about $9 \mathrm{db}$ in. winter and about $13 \mathrm{db}$ in summer. 


\section{The noise source}

During trawling, noise can conceivably be generated by any part of the trawling gear from the trawler itself to the trawl 450 feet $(137 \mathrm{~m})$ behind. The sources of noise in the different frequency bands in this project are unknown, but a measure of their location can be obtained from the data. If noise in the different frequency bands was produced by sources that are spatially separated from each other, the peak noise pressure in the different bands should occur at different times, and the difference should occur in all tows. Time differences between the peak noise in each band can be obtained from the distances $d$ of the Appendix. It will be remembered that $d$ is the distance from the intercept of each equation to the point at peak noise pressure. The maximum and minimum $d$ in each band are reflections of the distance interval of $146 \mathrm{ft}(44 \mathrm{~m})$ and $131 \mathrm{ft}(40 \mathrm{~m})$ between moving averages respectively. The time relationship between peak noise in the different frequency bands is the same for both distance intervals, calculations will be done with the maximum $d$ of each band. The d's in each recording can be put on a relative scale of time by the relationship $146 \mathrm{ft}$ $(44 \mathrm{~m})=30$ seconds. The relationships of peak noise pressure in the -bands of each of the 12 recordings are shown in Figure 9. It can be seen that there is no consistent time pattern between frequency bands. It can be concluded that any spatial separation between noise sources of the different frequency bands is too small to detect by examination of time differences between peak moving averages. If the trawl were a, major noise source in any frequency band, the 450 foot ( $137 \mathrm{~m}$ ) separation between the trawler and the trawl should cause a peak of about 1.5 minutes in that band in all recordings. The absence of any 


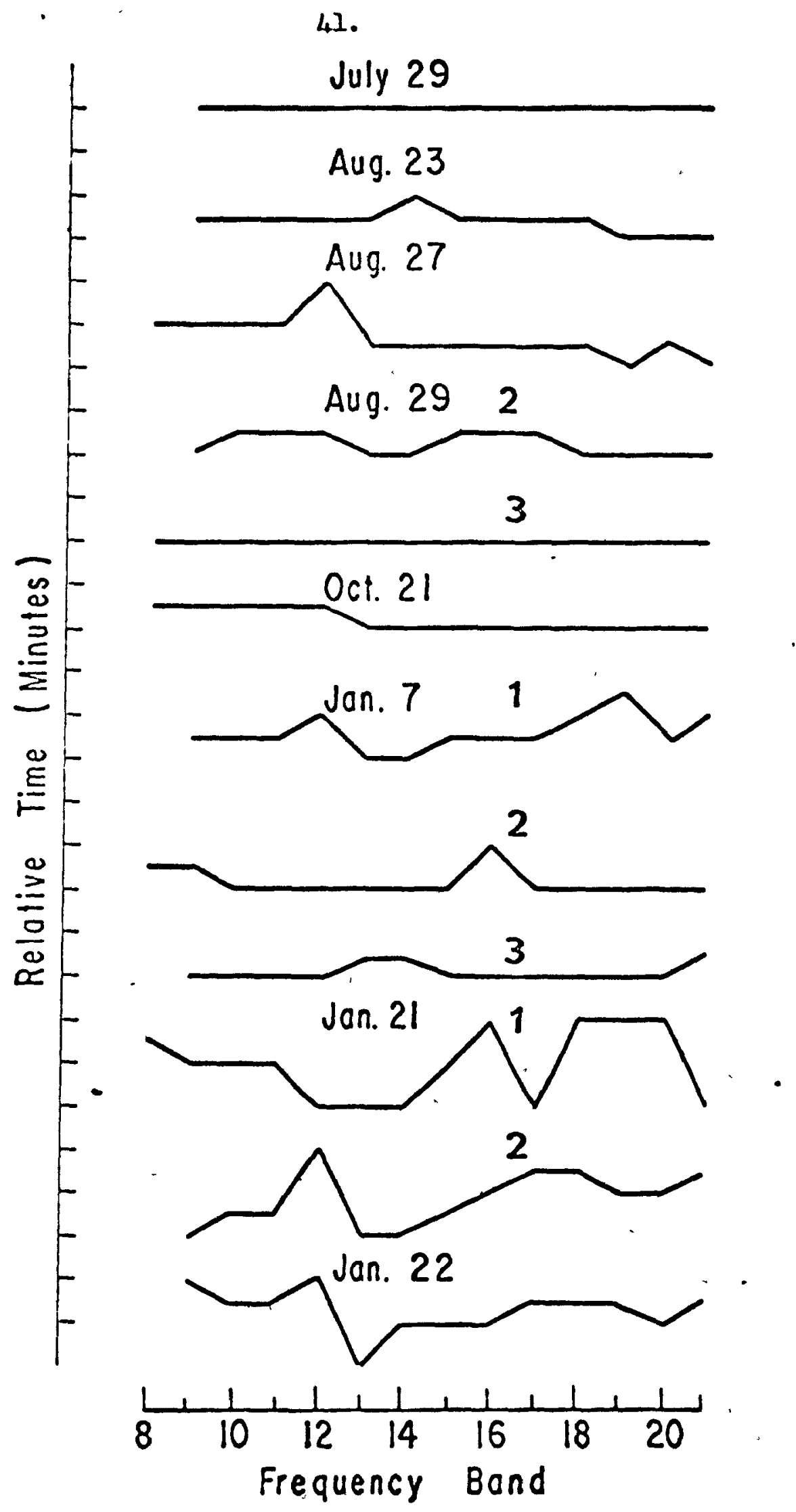

Figure 9. Relative time of peak notse pressure by frequency bands. 
such consistent pattern in Figure 9 leads to the conclusion that the major noise source, in all frequency bands, is the frawler. On a sea floor of soft mud as occurred in this project, the trawl would not be expected to produce much noise. This finding, also agrees with the statement of Shiskova (1958) that trawls produce little noise compared to trawlers. On a hard sea floor of rocks or gravel on the other hand the trawl could generate loud intermittent noises as its hard parts, such as doors and rollèrs, strike against the hard bottom.

D. Index value of trawling noise

Recent recommendations (Gjestland, 1971) suggest that ship noise and trawling noise should be described in terms of an index value that is the decibels in $1 \mathrm{~Hz}$ band widths at 1 meter from the source. In this project, distances between the noise source and the hydrophone were not determined precksely, and index values can therefore only be estimated. Urick 1967 (p. 266) states that "spherical or inverse spreading is a good rule of thumb for expressing the variation of ship noise with range at close distances, even for low frequencies in shallow water". This "rule of thumb" was used to calculate index values of trawling noise for the sumer and the winter data.

The mean noise level $\mathrm{db}_{\mathrm{cp}}$ at the closest distance between the hydrophone and the noise source and the mean noise level $\mathrm{db}_{\mathrm{cp}}+131$ at $131 \mathrm{ft}(40 \mathrm{~m})$ further than that were calculated from the minimum intercept (A), the slope (b) and the minimum distance (d) in each of the frequency bands of the Appendix. They were averaged in each band of the 6 sumer recordings and in each band of the 6 winter recordings, the averages and their standard errors are shown in Table 8. The 
43.

Table 8. Index values of summer data.

\begin{tabular}{|c|c|c|c|c|c|c|c|c|}
\hline ind & $d b_{c p}$ & $s \pi$ & $d b_{c p}+131$ & $\begin{array}{l}D C p \\
(f t)\end{array}$ & (m) & $-90 \%$ & $\begin{array}{l}x \text { yal } \\
\text { mean }\end{array}$ & +90 \\
\hline $\begin{array}{l}8 . \\
9 \\
10 \\
11 \\
12 \\
13 \\
14 \\
15 \\
16 \\
17 \\
18 \\
19 \\
20 \\
21\end{array}$ & $\begin{array}{r}3.7 \\
18.7 \\
34.8 \\
16.5 \\
3.6 \\
16.2 \\
17.7 \\
21.0 \\
20.2 \\
29.9 \\
39.4 \\
45.2 \\
33.9 \\
33.7\end{array}$ & $\begin{array}{l}1.3 \\
4.2 \\
5.8 \\
4.1 \\
2.2 \\
2.0 \\
2.4 \\
1.6 \\
1.6 \\
2.5 \\
3.6 \\
3.0 \\
2.5 \\
1.9\end{array}$ & $\begin{array}{r}11.2 \\
11.4 \\
28.4 \\
10.9 \\
4.9 \\
10.9 \\
11.6 \\
15.3 \\
15.0 \\
23.8 \\
32.4 \\
36.8 \\
31.9 \\
26.5\end{array}$ & $\begin{array}{r}262 \\
101 \\
119 \\
146 \\
262 \\
164 \\
131 \\
146 \\
164 \\
131 \\
109 \\
82 \\
94 \\
101\end{array}$ & $\begin{array}{l}80 \\
31 \\
36 \\
44 \\
80 \\
50 \\
40 \\
44 \\
50 \\
40 \\
33 \\
25 \\
29 \\
31\end{array}$ & $\begin{array}{l}33.9 \\
34.9 \\
49.7 \\
34.2 \\
33.4 \\
36.2 \\
34.1 \\
38.8 \\
37.9 \\
43.1 \\
48.3 \\
51.7 \\
46.4 \\
41.8\end{array}$ & $\begin{array}{l}36.7 \\
41.9 \\
59.3 \\
40.9 \\
37.0 \\
39.6 \\
38.1 \\
41.4 \\
40.6 \\
47.3 \\
54.2 \\
56.6 \\
50.5 \\
44.9\end{array}$ & $\begin{array}{l}38.3 \\
48.9 \\
68.9 \\
47.6 \\
40.6 \\
43.0 \\
42.7 \\
44.0 \\
43.3 \\
51.4 \\
60.7 \\
67.5 \\
54.6 \\
48.0\end{array}$ \\
\hline
\end{tabular}

Index values of winter data.

$\begin{array}{rrrrrrrrr}8 & -7.9 & 6.1 & -8.6 & 1310 & 400 & 28.6 & 38.5 & 48.4 \\ 9 & 6.7 & 3.5 & 4.3 & 437 & 133 & 36.8 & 42.5 & 48.2 \\ 10 & 34.5 & 5.3 & 29.0 & 146 & 44 & 51.2 & 59.9 & 68.6 \\ 11 & 18.0 & 3.8 & 14.4 & 262 & 80 & 41.7 & 47.4 & 53.1 \\ 12 & 2.4 & 3.5 & .3 & 655 & 200 & 33.1 & 38.8 & 44.5 \\ 13 & 13.6 & 1.6 & 10.8 & 327 & 100 & 40.3 & 43.0 & 45.7 \\ 14 & 7.5 & 1.6 & 5.0 & 437 & 133 & 35.7 & 33.3 & 40.9 \\ 15 & 10.0 & 3.2 & 7.0 & 327 & 100 & 32.2 & 37.4 & 42.6 \\ 16 & 12.2 & 2.9 & 10.0 & 437 & 133 & 36.2 & 41.0 & 45.8 \\ 17 & 24.3 & 3.3 & 20.7 & 218 & 66 & 40.6 & 46.3 & 51.6 \\ 18 & 22.7 & 5.0 & 19.3 & 262 & 80 & 36.9 & 45.1 & 53.3 \\ 19 & 17.8 & 4.4 & 15.0 & 327 & 100 & 34.0 & 41.2 & 48.4 \\ 20 & 15.4 & 4.1 & 12.7 & 327 & 100 & 31.1 & 37.8 & 44.5 \\ 21 & 15.6 & 3.4 & 12.8 & 327 & 100 & 31.5 & 37.0 & 42.5\end{array}$

$d b c p=$ average decibels at closest point

$s \bar{x}=$ standard error

$d b_{c o}+131=$ average decibels at closest point +131 feet DCp = distance at closest point

$\pm 90 \%=$ upper and lower $90 \%$ fiducial limits. 


\section{4.}

average values were used to calculate a distance (Dcp) between the closest point and the hydrophone in the following manner.

The slope between the two averages in any band is (according to U'ick's "rule of thumb") - $20 \mathrm{log}$ distance. In any band, therefore,

$$
\begin{aligned}
& d b_{c p}=A-20 \log D_{c p} \\
& d b_{c p}+131=A-20 \log \left(D_{c p}+131\right) . \text { These equations can }
\end{aligned}
$$

be subtracted and reduced to

$$
\text { Dcp }=\frac{131}{\frac{{ }^{a n t i l o g}-d b_{c p}+131}{20}-1}
$$

Since $d b_{c p}\left( \pm\right.$ standard error) and $D_{c p}$ are now known, the decibels at 1 meter $(\mathrm{dbm})$ can be calculated by the following equation

$$
d b m( \pm \text { standard error })=d b_{c p}( \pm \text { standard error })-20 \log \frac{3.28}{D_{c p}}
$$

(I meter 3.28 feet.) These distances Dcp are also listed in Table 8. The decibels at 1 meter are band levels and can be conerted to levels in $1 \mathrm{~Hz}$ band widths by subtracting, in each band, the appropriate power, ratio of Table 2 . The converted values are index values of trawling noise and are shown in Table 8 and Figure 10.

The index value for the sumer and the winter data should be the same if the "rule of thumb" used in their calculation is valid for both situations. At frequencies up to $125 \mathrm{~Hz}$ the index values for the sumer and winter are very close, but at frequencies between 125 and $315 \mathrm{~Hz}$ the calculated values for winter are from 8 to $15 \mathrm{db}$ lower than those of summer. If it can be taken for granted that the trawler generates an equal amount of nolse in winter as in summer, the difference indicates that the "rule of thumb" does not apply to both sumer and 


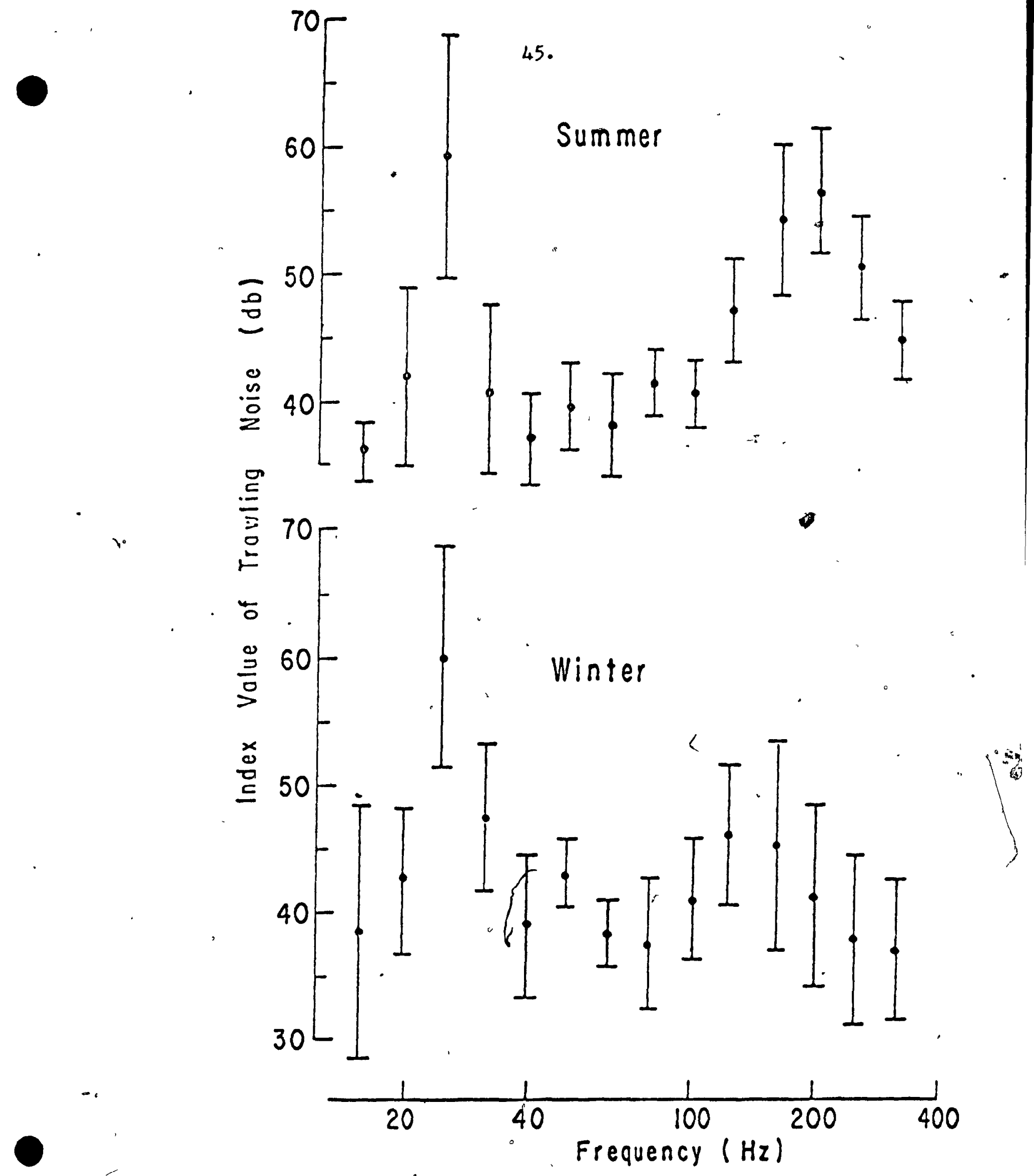
Figure 10 . Index values of trawling noise for winter and
summer data. 
5

\section{6.}

winter conditions.

At frequencies between 125 and $315 \mathrm{~Hz}$ the transmission loss

of $20 \mathrm{log}$ distance does not fit both the summer and the winter conditions. If it is appropriate for summer, the winter loss should be about $35^{\circ}$ : $\log$ distance. If it is appropriate for winter, the summer loss should be about $12 \log$ distance. Which of these cases, if either, is correct, cannot be determined from the data. It is correct to conclude, however, that transmission loss in winter, at close range and at frequencies. between 125 and $315 \mathrm{~Hz}$, is more than in sumer.

The spectrum of index values calculated here shows similarities to those reported by Olsen (1967) and by Hawkins et al. (1972). The spectrum of the vessel $\mathrm{R} / \mathrm{V}$ Johan Hjort (Olsen, 1967) shows a decrease in level at around $40 \mathrm{~Hz}$ and a peak at around $125 \mathrm{~Hz}$ that is similar to the distribution presented here. Olsen does not report a peak at $25 \mathrm{~Hz}$ in the $1 / 3$ octave band analysis of the Johan Hjort noise, but he does show a $68 \mathrm{db}$ noise level in a $1 \mathrm{~Hz}$ band width at $25 \mathrm{~Hz}$. If this $68 \mathrm{db}$ in a $1 \mathrm{~Hz}$ band width were measured in a $1 / 3$ octave band width with a center frequency of $25 \mathrm{~Hz}$, the level would be about $60 \mathrm{db}$. This is almost exactly the level of the peak at $25 \mathrm{~Hz}$ in this report, and suggests that the peak is due to high noise intensity in a very narrow band around $25 \mathrm{~Hz}$.

The spectra of the other vessels reported on by Olsen (1967) and Hawkins et al. (1972) do not show a peak in noise level between 100 and $200 \mathrm{~Hz}$. They show a decrease in noise with increasing frequency of about $6 \mathrm{db}$ per octave at frequencies above $100 \mathrm{~Hz}$.

The highest mean noise level described by Hawking et al. was about $50 \mathrm{db}$ and occurred below $100 \mathrm{~Hz}$. The highest mean noise level 
47.

\section{moported by olson was about $69 \mathrm{db}$ at about $40 \mathrm{Ms}$.}

At $200 \mathrm{~Hz}$ the arerage nolse of the 2 vessels reported on by Olsen, and the average of the 2 vessels reported on by Hawkins et al. were about 45 and $40 \mathrm{db}$ respectively.

In the present work, the average at $200 \mathrm{~Hz}$ was 56 and $4 \mathrm{ldb}$ in summer and winter respectively. This might be regarded as evidence that the winter spectrum is more representative of average conditions and that the winter transmission loss at close range really is 20 log distance.

In general, the noise levels determined by Olsen (1967), Hawkins et al. (1972) and in this project are surprisingly similar when Q

one considers the differences in conditions under which measurements were made, and the differences in vessel size, type and propulsion. It shows that smaller wooden vessels can be as noisy as the larger steel vessels,

E. Transmission loss

Transmission loss describes the weakening of sound between a reference distance from a sound source and other distances. If I is the intensity of a source at a reference distance, and $I_{2}$ is the intensity of another distance, the transmission loss between the two distances is $10 \log \frac{I_{1}}{I_{2}} \mathrm{db}$. Transmission loss is the sum of loss due to spreading and of loss due to attenuation. Spreading loss is a geometrical effect representing the regular weakening of a sound signal as it spreads, outward from a source. If a source generates sound in an unbounded homogeneous medium, the power is radiated equally in all directions so as to be equally distributed over the surface of a sphere surrounding the source. This is called spherical spreading. If there 
48.

is no loss in the medium, the power crossing all such spheres must be

the same. Since power equals intensity times area,

$$
\begin{aligned}
& \cdot P=4 \pi r_{1}^{2} I_{1}=4 \pi r_{2}^{2} I_{2}= \\
& (P=\text { power, } r=\text { range, } I=\text { intensity })
\end{aligned}
$$

If $r_{1}=1$ the transmission loss to $r_{2}$ will be $10 \log \frac{I_{1}}{I_{2}}=10 \log r_{2}^{2}=$ $20 \log r_{2} d b . r_{i}$

If the medium has plane and parallel upper and lower bounds such as in shallow water, the spreading is no longer spherical. It is called cylindrical spreading because beyond a certain range the power radiated by a sourge is distributed over the surface of a cylinder with radius $(r)$ equal to the range, and height $(H)$ equal to the distance between the bounding planes. The power crossing such surfaces at range $r_{1}$ and $r_{2}$ is

$$
P=2 \pi r_{1} H I_{1}=2 \pi r_{2} H I_{2}=\ldots \cdot-
$$

If $r_{1}=1$ the transmission loss is

$$
10 \log \frac{I_{1}}{I_{2}}=10 \log r_{2}
$$

In the ocean the distinction between spherical and cylindrical spreading is never quite so clear. In fact, spherical spreading often occurs under trapping conditions in sound channels where it has no right to occur (Urick, 1967).

Attenuation, the other factor that adds to transmission Ioss, is the reduction in intensity due to discontinuities, absorption, and variatiogs in temperature and salinity. It thus includes all factors other than spreading 1oss. It is not a constant, and cannot be accurately predicted from theoritical considerations.

Transmission loss in this project was not measured but the 
49.

slopes (b) of the Appendix are functions of the transmission chatracteristics of trawling noise for the prevailing conditions. They do not express the real magnitude of the transmission losses because they were calculated from an assumed distance between the last moving average and the hydrophone. They do express the relative transmission loss between frequencies. It was shown previously that there was no evidence of spatial separation between noise sources of the different frequency bands. The distance between the hydrophone and closest point in the tow path, therefore, can be expected to be the same for all bands of any one recording. The difference between this distance and the assumed distance from which the slopes were calculated is, therefore, constant and the error in slope also is constant for all bands in any one recording. The slopes in each band of the 6 sumner recordings and of the 6 winter recordings were averaged and are shown with their $90 \%$ fifucial limits in Figure 11.

It can be seen that the relationship between slopes and frequencies is the same in summer and winter, but that the slopes in winter are approximately $10 \mathrm{db}$ higher. Greater transmission loss in summer has also been reported for the Scotian Shelf by Macpherson et al. (1962). Their data indicate that a difference between sumer and winter of 10 log distance is not unreasonable. They attribute the difference to the positive vertical velocity profile of winter, which as already discused also occurs in Passamaquoddy Bay.

The variations of transmission loss with frequency seen in Figure 11 may be due to several causes, singly or in combination. The patterns could reflect an interaction between the wave lengths of the frequencies and the physical characteristics of the transmission channel, 
50.

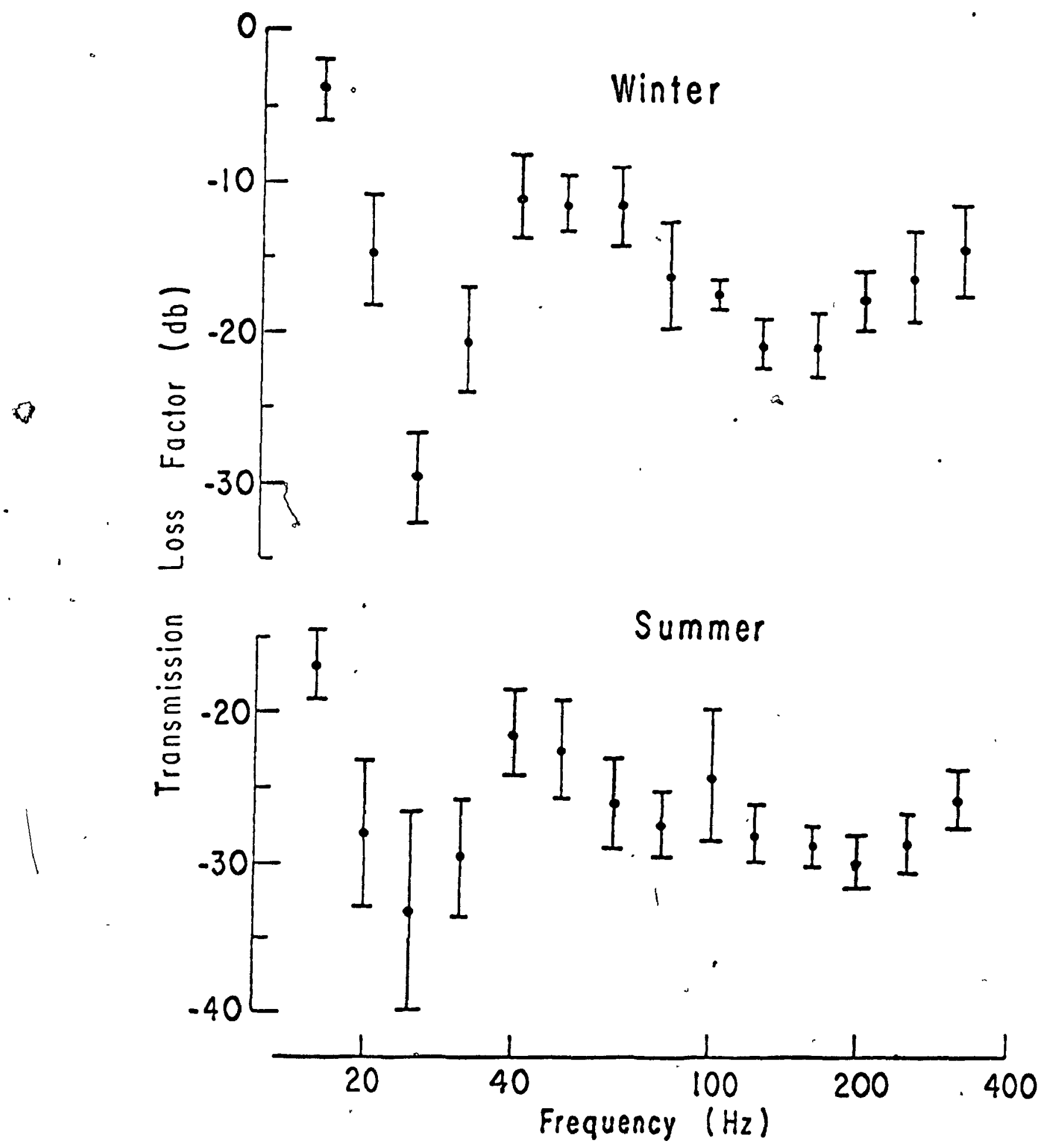

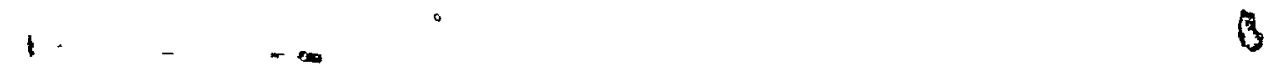

Figure 11. Mean relative transmission loss by frequencies. 
51.

or they could be caused by the characteristics of the noise fields generated by the sources of the different frequency bands. Whatever the cause, it is important to note that transmission loss does vary with frequency by as much as $2619 \mathrm{~g}$ distance in the frequency range covered in this report.

F. Range at which cod can detect trawling noise

The maximum and minimum range ( $R$ in the Appendix) at which cod can detect trawling noise in each band were averaged for the six sumer recordings and the six winter recordings. The means of sumer and winter in each band are listed with their standard deviation in Table 9. Winter ranges are significantly greater at 25 and $31.5 \mathrm{~Hz}$ ('t' test). Sumer ranges are significantly greater at 20,40,200 and $250 \mathrm{~Hz}$. At other frequencies, the differences are not significant. The mean maximum and minimum range of each band and their upper and lower $90 \%$ fiducial limits respectively are shown in Figure 12 for the summer recordings, and in Figure 13 for the winter recordings.

In summer the trawling noise at $200 \mathrm{~Hz}$ can be detected ạt the longest range, It can be detected at about $1.5 \mathrm{miles}(2.8 \mathrm{~km})$ in $90 \%$ of the tows made under conditions similar to those during this project. In $10 \%$ of the tows it can be detected as far as 2.5 miles $(4.6 \mathrm{~km})$. In winter the frequency that can be detected at the longest range is $125 \mathrm{~Hz}$. It can be detected at about .5 miles $(.9 \mathrm{~km})$ and at about 2.5 miles $(4.6 \mathrm{~km})$ in $90 \%$ and $10 \%$ of the tows respectively. Except for the increased ranges at frequencies 20,25 and $31.5 \mathrm{~Hz}$ the range at frequencies below $200 \mathrm{~Hz}$ decreases with frequency at about $66 \mathrm{ft}(20 \mathrm{~m})$ per $\mathrm{Hz}$ in sumer. In winter this decrease is not as clear because of the large difference in range between 40 and $50 \mathrm{~Hz}$. 
52.

Table 9. Mean range at which cod can detect trawling nolse in summer and winter.

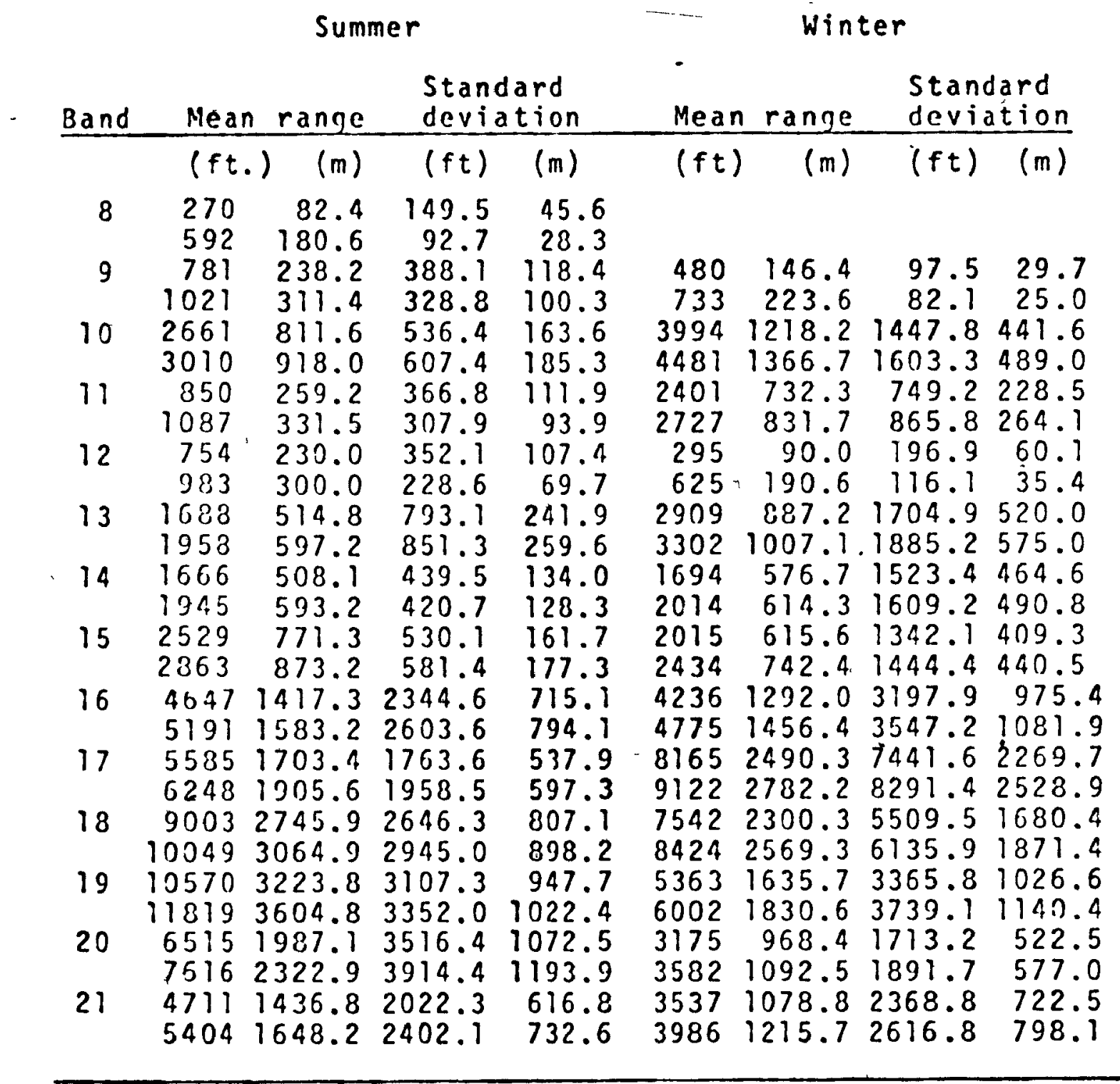




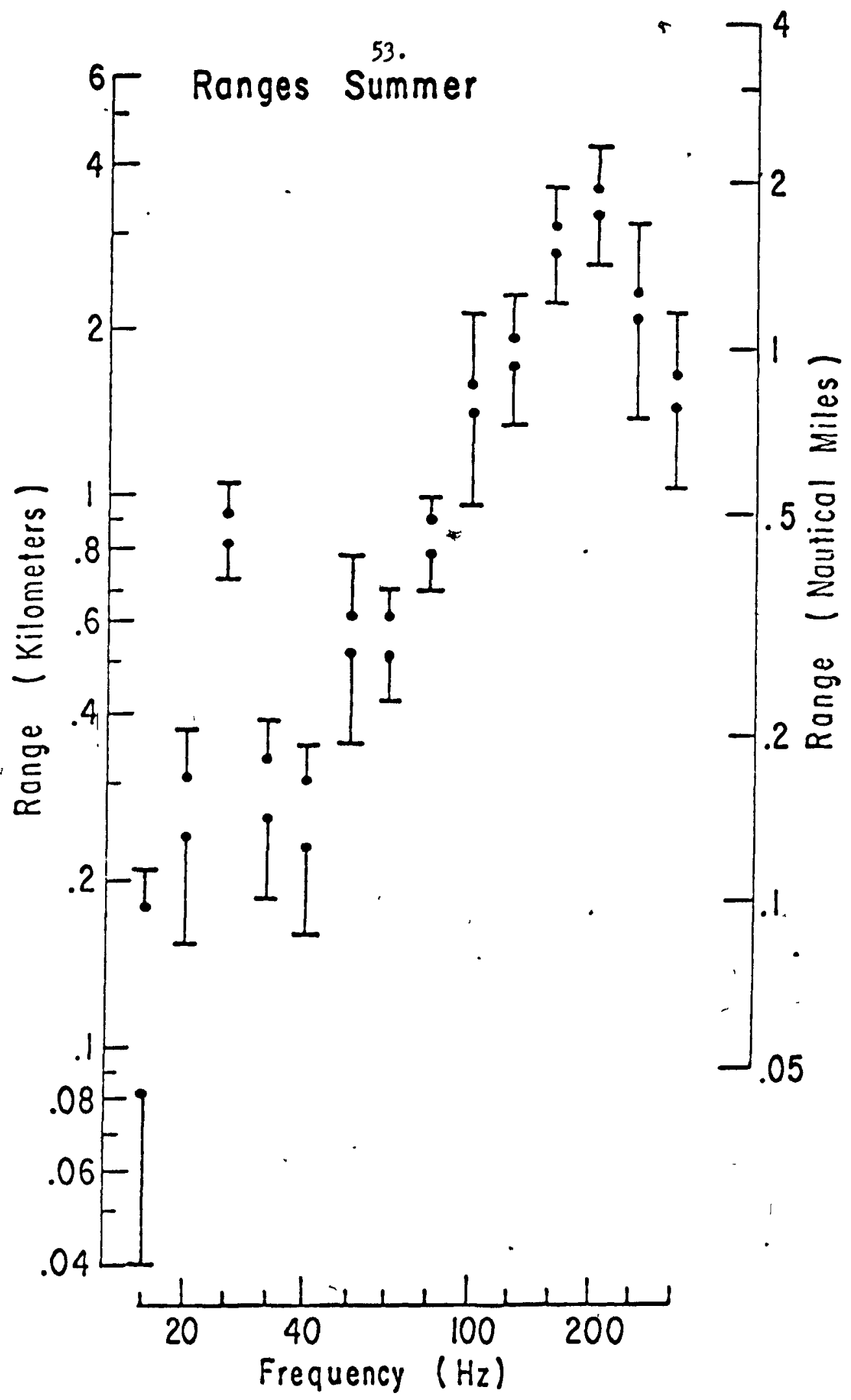

Figure 12. Mean maximum and minimum range at which cod can detect trawling noise in summer and their upper and lower $90 \%$ fiducial 1 imit respectively. 


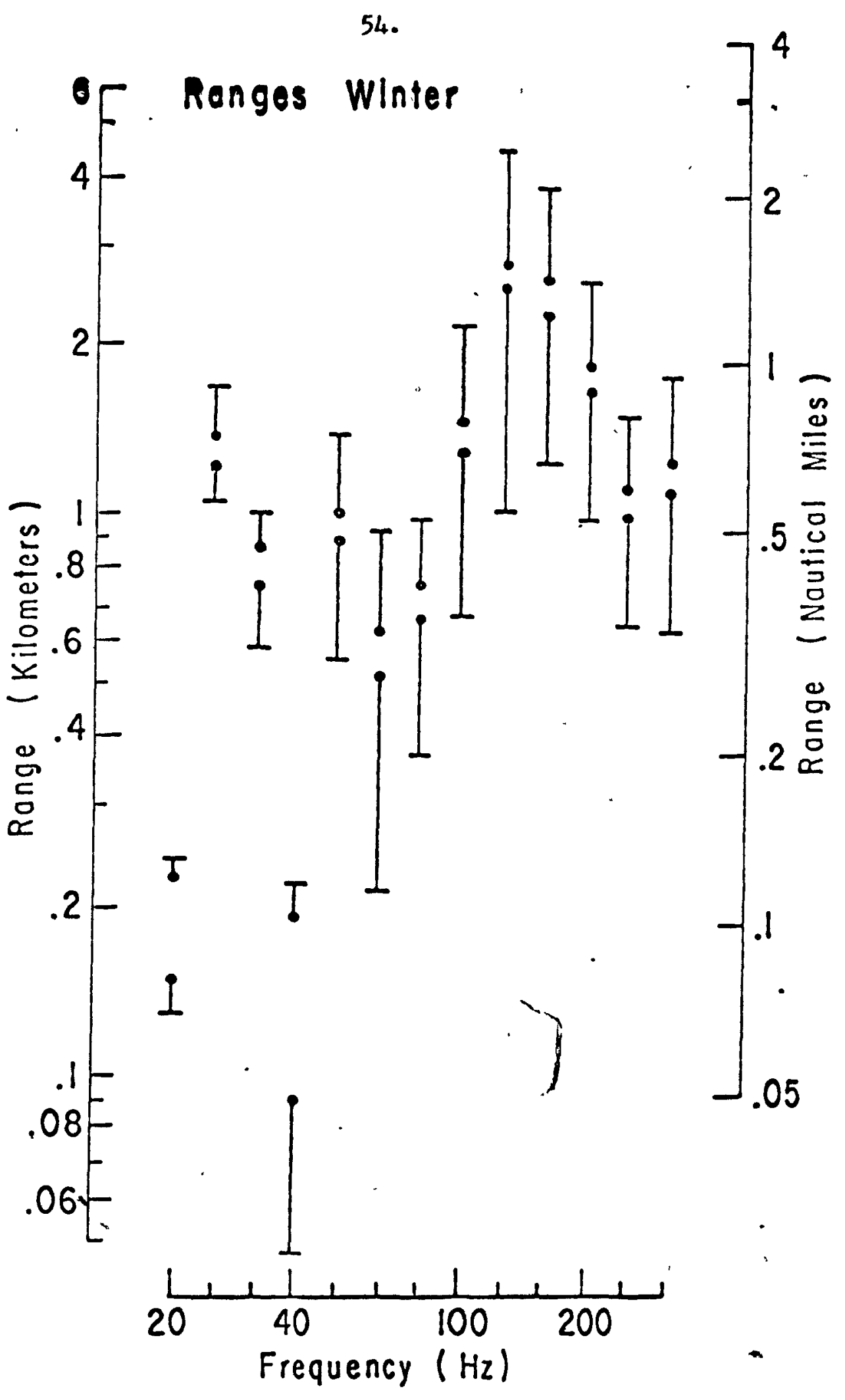

Figure 13. Mean maximum and minimum range at which cod can detect trawling noise in winter, and their upper. and lower $90 \%$ fiducial ifmit respectively. 
55.

At frequencies above $200 \mathrm{~Hz}$ the range decreases with increasing frequeney at about $40 \mathrm{ft}(1 \mathrm{~m} \mathrm{~m})$ por $\mathrm{Hs}$ in winter and in sumer. The shape of the spectrum of range versus frequency is different from the spectrum of index values (Figure 10). The index values were highest at $25 \mathrm{~Hz}$ in sumer and winter. The fact that $25 \mathrm{~Hz}$ is not the frequency that is detected at the longest range can be attributed to the greater transmission 2039 at $25 \mathrm{~Hz}$ than at 125 and $200 \mathrm{~Hz}$ (Figure 11). This points out that the theoretical values for transmission loss whether for spherical spreading (20 log distance) or for cylindrical spreading ( $10 \mathrm{log}$ distance) should not be used in calculations involving transmission of noise over long ranges in shallow water.

As mentioned, the frequencies of trawling noise that cod can detect at the longest ranges are 125 and $200 \mathrm{~Hz}$ in winter and summer respectively. Since range is a function of masking level, and masking level depends on the ambient noise level, the effect of ambient noise level on range can be determined.

To simplify these calculations the mean of the average maximum and average minimum range (from Table 9) were calculated for $125 \mathrm{~Hz}$ in winter and for $200 \mathrm{~Hz}$ in sumer. Because this mean range was calculated from a masking level based on the mean average ambient nolse level, the mean range changes with ambient noise level by a factor equal to

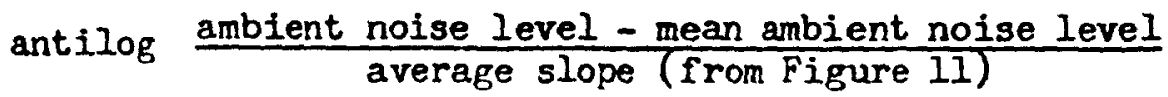

when all factors except ambient noise level remain the same. The relationship of range versus ambient noise was calculated for the mean ranges and the lower $90 \%$ fiducial limits of the average minimum ranges of $125 \mathrm{~Hz}$ for winter and of $200 \mathrm{~Hz}$ for 3ummer. They 
56.

are show in Figure 14. The range of amblent nolse levels ohown in Figure 14 includes the maximum, mean and minimum average amblent noise measured in this project, and extends lower to $-50 \mathrm{db}$ because that is about the lowest level of ambient noise; at these frequencies, that occurs in the ocean (Pigott, 1964; Wenz, 1962).

It can be seen that the steeper slope $(-30)$ of sumer results in less change of range with change in ambient noise level than does the less steep slope (-2I) of winter. It can also be seen that at any noise level likely encountered in the ocean, winter ranges are larger than summer ranges.

Under the most auiet condition of ambient noise, cod can detect trawling noise at a mean range of about 35 miles $(60 \mathrm{~km})$ in winter and about 10 miles $(18 \mathrm{~km})$ in summer.

In $90 \%$ of tows made under such conditions, cod can detect the noise at about 14 miles $(25 \mathrm{~km}$ ) in winter and at about 7 miles $(13 \mathrm{~km})$ in summer.

Even at the loudest ambient noise level of $-15 \mathrm{db}$ that is likely to occur in the ocean at these frequencies (Wenz, 1962), the range at which cod can detect trawling noise is appreciable. In winter the mean range is about .9 miles $(1.7 \mathrm{~km})$; in summer it is about .6 miles $(1.1 \mathrm{~km})$.

In summary, the mean detection range of trawling noise for cod ranges from 99 miles $(1.7 \mathrm{~km})$ to 35 miles $(60 \mathrm{~km})$ in winter and from .6 miles $(1.1 \mathrm{~km})$ to 10 miles $(18 \mathrm{~km})$ in sumer as the ambient noise level ranges from the loydest to the least loud.

\section{Conclusion}

It has been shown that the ambient noise measured in this project is similar to, and well within the limits of ambient noise in other reports 


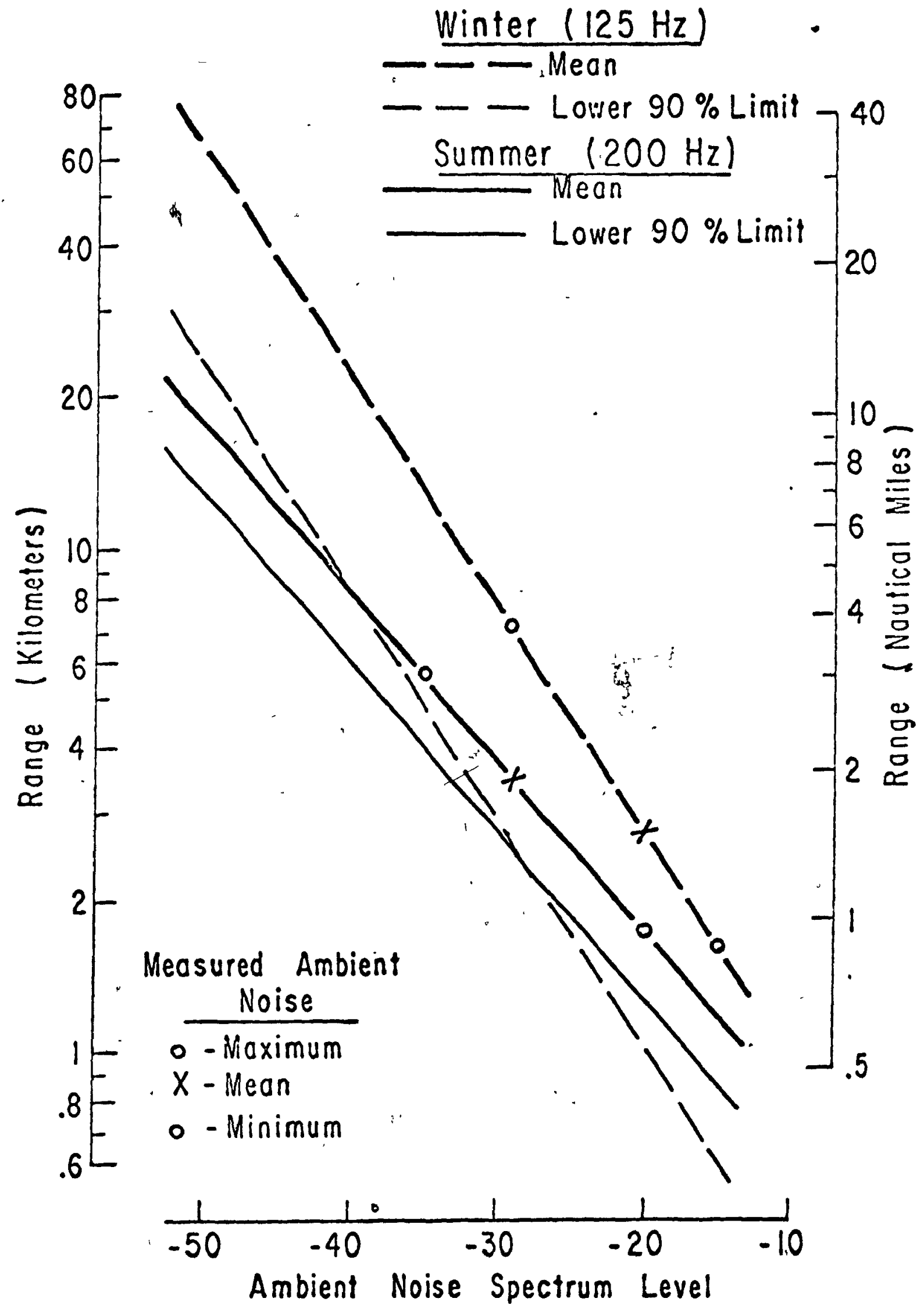

Figure 34. Effect of ambient noise level on range at which cod can detect trawling noise in summer and winter. 
(Piggott, 1964; 'Wonz, 2962). It has been shom that the Index value of trawling nolse (and thus the nolso generated by trawling) estimated in this report is similar to that reported for both trawlers and seiners (Hawkins et al. 1972; 0lsen, 1967). The transmission loss estimated in this report showed variations with frequency that have not been shown before but was similar in magnitude to that described for broadband sources on the Scotian Shelf (Macpherson et al. 1962).

These considerations can lead to the conclusion that altinough the measurements were made under a specific range of conditions, they do reveal generalities that have a more universal application.

It may be concluded that in areas where the vertical sound velocity profile is positive in winter and negative in summer, the range at which cod can detect trawling noise is longer in winter than in summer when the ambient noise is the same. The longer range in winter is probably due to surface duct transmission in which sound propagates by upward refraction and repeated reflections off the sea surface where there is little reflection loss. In summer, refraction is downward and reflection loss at the bottom is generally higher than at the surface.

The frequencies of trawling noise that are propagated the furthest also differ between winter and sumner. In winter, frequencies in the third octave band centered at $125 \mathrm{~Hz}$ can be detected at the longest range, while in summer, frequencies in the third octave band centered at $200 \mathrm{~Hz}$ can be detected furthest. This difference also must be attributed to the different propagation characteristics between winter and summer.

In both winter and sumer, the range at which cod can detect trawling noise varies inversely with,ambient noise level. During the most quiet conditions likely encountered in the ocean, cod should be able to detect 
trawling nolso as far as $35 \mathrm{miles}(60 \mathrm{~km})$ away in winter, and as far as $10 \mathrm{miles}(10 \mathrm{~km})$ away in aumer. Under the most noloy conditions I1kely encountered in the ocean, the range at which cod can detect trawling noise is still appreciable. On the average, cod can detect the noise of tows made under such conditions at about .9 miles $(1.7 \mathrm{~km})$ in winter, and at about .6 miles $(1.1 \mathrm{~km}$ ) in sumer.

It is obvious that trawling generates auditory stimuli that should, in theory, allow cod to make avoidance maneuvers well in front of the trawl under all conditions of ambient noise. The fact that cod are captured by trawls at all could mean that they do not respond to the stimuli, or that some respond in a way that does not lead to avoidance.

To determine which of these interpretations, if either, is correct is not within the scope of this report. It is hoped that the results presented here will aide in the design of experiments to determine the behaviour of cod in relation to fish capture processes.

\section{J Acknowledgements}

This project was facilitated by the work of S. M. Polar on the electronics, and by the cooperation of Captain P. T. Ossinger. Very special thanks are due to A. Sreedharan and G. E. Fawkes for the computer programming, and for their help in data analysis. 


\section{Reforenees}

Albers, V. M. 1965. Underwater Acoustics Handbook II. Pennsylvania State University Press, University Park, Pennsylvania.

Aslanova, N. E. 1958. A study of the behaviour of fishes in the zone of action of fishing gear. Ministry of Agr. Fish. Food translation N. S. No. 15. From: The Behaviour of Fish and Commercial Searching Trudy UNIRO 36, 33-51, 1958.

Bagenal, T. B. 1958. An analysis of the variability associated with the Vigneron-Dahl modification of the otter trawl by day and night . and a discussion of its activity. J. Cons. perm. int. Explor. mer, $24,62-79$.

Beamish, F. W. H. 1966. Reaction of fish to otter trawls. Fish. Can. 19(5): 19-21.

Brandt, v. A. 1959. Einschiff-Schwinm Schlepp Netz Versuche mit dem F. D. "Redensburg" in der Zeit vom 28. 10 bis 12.11 .59 in der Irischen See und im Kanal. Protokolle zur Fischereitechnik Heft. 27/28, Bd. VI, p: 190-212.

Buerkle, U. 1967. An audiogram of the Atlantic cod, Gadus morhua L. J. Fish. Res. Bd. Canada, 24 (II): 2309-2319.

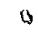
1968. Relation of pure tone thresholds to background noise level in the Atlantic cod (Gadus morhua)." J. Fish. Res. Bd. " ; Canada, 25(6): $1155-1160$.

1969. Auditory masking and the critical band in Atlantic 's, cod (Gadus morhua). In J. Fish. Res. Bd. Canada 26(5): 1113-1119. Chảpman, C. J. and A. D. Hawkins. 1967. The importance of so und "iñ fișh . behaviour in relation to capture by trawls. FAO Conference on Fish Behaviour in Relation to Fishing Techniques and Tactics. 
61.

Agende 1tem 4, FR: FB/67/E/42.

Chapman, C. J. 1970. Sh1p nolse and hearing in f1sh. In Scot. F1sh. Bull. No. 33: 22-24.

Forgeron, F. D. 1959. Temperature and salinity in the Quoddy region. $\$$

Ințernational Passamaquoddy Fisheries Board Report to: International Joint Commission, Ottawa, Ont., and Washington, D. C.

Freytag, G. 1967. Zur Frage der Messgenauigkeit bei hydrobioakustischen Untersuchungen in Aquarien und Flachwassergebieten. Helgoländer wiss. Méeresunters., 15; 376-389.

Gjestland, T. 1972., Noise measurements in fishing vessels. The Univ, Norway, Trondheim, Norway, KLEA 481.

Hawkins, A. D., D. N. MacLennan and G. Urquhart. 1972. Report on noise trials of two motor trawlers. Dept. of Agr. and Fish. of Scotland, - Marine Lab. Internat. Report No. 72-11. (Unpublished typescript.) Hawkins, A. D. and C. J. Chapman. 1969(a). Noise trials F. V. "Semla". Dept. of Agr. and Fish. of Scotland, Marine Laboratory Aberdeen - $A B 9$ 8DB Scotland. (Unpublished typescript.)

1969(b). A field determination of hearing thresholds for the cod, Gadus morhua L. In International working group for fishing technology. Report of the 8th IF meeting, Lowestoft, 29-30 April, pp. 89-97.

Hemings, C. C. 1967. Divers obsèrve the Danish seine net. Scottish Fisheries. Bulletin No. 27, p. 17-20.

Iversen, R. T. B. 1969. Auditory thresholds of the scombrid fish. Euthynnus affinis with corments on the use of sound in tuna fishing. FAO Fisheries Report No. 62, Vol. 3, p. 849-859.

- Kiselev, 0. N. 1968. Visual observations of fish behaviour in natural 
62.

conditions; In Fish Behaviour and Fishing Techniques, All Union Conference at Murmansk 1968. Translated from Russian by Israel Program for Scientific Translations 1971.

Korotkov, V. K. 1969. The behaviour of some fish species in a trawl. In Probl. Ichthyolog,y, 9(6): 893-899.

Lagunov, I. I. 1955. Underwater observations from a submersible chamber. From: Ryb. Khoz., (8): 54-57. Canada Fish. Res. Bd. Transl. Ser. No. 2217, 13 p., 1972 .

Macpherson, J. D. and N. O. Fothergill. 1962. Study of low-freauency sound propagation in the Hartlen Point Regiop of the Scotian Shelf. Journal of Acoustical Society of America, Vol. 34, No. 7, p. 967971.

Maniva, Y. 1970. Effect of vessel noise in purs'e, seining. FAO conference on fish finding, purse seining and aimed trawling. Reykjavik 1970 Martyshevskii, U. N., and V. K. Korotkov. 1968. Behaviour of some fish in the zone of action of the trawl. In Fish Behaviour and Fishing Techniques All Union Conference held at Murmansk, 27 Feb. to 1 March 2968. Translated Srom Russian by Israel Program for Scientific translations, Jerusalem 1971.

Olsen, K. 1967. A comparison of acoustic threshold in cod with recordings of ship noise. From: FAO Conference on Fish Behaviour in Relation to Fishing Techniques and Tactics. Agenda item 3.

1969. Directional hearing in cod (Gadus morhua L.). In International working group for fishing technology. Report of the 8th IF meeting, Lowestoft, 29-30 April, pp. 77-88. 1970. Influence of vessel noise on behaviour of herring. FAO conference on fish finding, purse seining, and aimed trawling 


\section{3.}

held at Reykjavik, 24-30/5/1970, No. FF/70/63.

1971. Influence of vessel noise on behaviour of herring. In Modern Fishing Gear of the World - 3 (ed. H. Kristjonnson). Fishing News (Books) Itd., London.

Parrish, B. B., Blaxter, J. H. S., and Dickson, W. 1962. Phatography of fish behaviour in relation to trawls. ICES Comparative Fishing Comnittee Paper №: 77.

Piggott, C. L. 1964. Ambient sea noise at low frequencies in shallow

water on the Scotian Shelf. J. Acoust. Soc. Amer. 36(11): 21522163.

Schärfe, J. 1951, Zur Fragè der Fischscheuchung durch Lotschall. Reprint: Fischereiwelt, \#2: 30-3l.

1956. Echolotbeobachtungen über die Geräuscherzeugung durch das Rollengrundtau. 'Reprint: Fischwirtschaft, 9: 250.

1959. Fortsetzung der Eunschiff-Swimm-Schleppnetz fischerei mit dem F. D. Regensburg in der Zeit vom 12. bis 27.9, 1959 in der Nordsee. Protok. Fish. Tech. Bd. 4, H27/28, 156-189.

Shiskova, E. V. 1958. Concerning the reaction of fish to sound and the spectrum of trawler noise. (Translated from MSS by J. M. Moulton, Bowdoin College 1960.) Rybnoe Khoziaistvo 34(3): 33-39.

Schubert, K. 1950. Fischlotungeh. Fischereiwelt $2 ; \overline{\mathrm{p}}$. 151-152.

Urick, R. J. 1967. Principles of underwater sound for engineers. McGraw Hill Book Co., New York.

Wenz, G. M. 1962. Acoustic ambient noise in the ocean: spectra and sources. J. Acoust. Soc. Amer. 34: 1936-1956. 


\section{APPENDIX}

Intercept (A), slope (b), masking level (ML), distance (d) for 6 summer and 6 winter recordings ( $R$ and $d$ in.feet).

July 29, 1970, recording 1 .

\begin{tabular}{|c|c|c|c|c|c|}
\hline Band & $\begin{array}{c}\text { Intercept } \\
\text { (A) }\end{array}$ & $\begin{array}{c}\text { Slope } \\
\text { (b) }\end{array}$ & $\begin{array}{c}\text { Masking } \\
\text { ievel } \\
\text { (iiL) }\end{array}$ & $\begin{array}{c}\text { Distance } \\
\text { (d) }\end{array}$ & $\begin{array}{c}\text { Range } \\
(R)\end{array}$ \\
\hline 9 & $\begin{array}{l}28.12 \\
28.83\end{array}$ & -15.05 & -14 & $\begin{array}{l}262 \\
292\end{array}$ & $\begin{array}{l}370 \\
646\end{array}$ \\
\hline 10 & $\begin{array}{l}64.16 \\
65.16\end{array}$ & -23.79 & -15 & $\begin{array}{l}262 \\
292\end{array}$ & $\begin{array}{l}1854 \\
2110\end{array}$ \\
\hline 11 & $\begin{array}{l}35.46 \\
36.39\end{array}$ & -19.76 & -16 & $\begin{array}{l}262 \\
292\end{array}$ & $\begin{array}{l}149 \\
524\end{array}$ \\
\hline 12 & $\begin{array}{l}44.99 \\
45.96\end{array}$ & -20.65 & -18 & $\begin{array}{l}262 \\
292\end{array}$ & $\begin{array}{r}862 \\
1082\end{array}$ \\
\hline 13 & $\begin{array}{l}75.87 \\
77.19\end{array}$ & -28.18 & -20 & $\begin{array}{l}262 \\
292\end{array}$ & $\begin{array}{l}2262 \\
2568\end{array}$ \\
\hline 14 & $\begin{array}{l}91.00 \\
92.58\end{array}$ & -33.64 & -22 & $\begin{array}{l}262 \\
292\end{array}$ & $\begin{array}{l}2025 \\
2310\end{array}$ \\
\hline 15 & $\begin{array}{l}93.20 \\
94.76\end{array}$ & -32.97 & -24 & $\begin{array}{l}262 \\
292\end{array}$ & $\begin{array}{l}3.326 \\
3742\end{array}$ \\
\hline 16 & $\begin{array}{l}86.21 \\
87.69\end{array}$ & -31.54 & -22 & $\begin{array}{l}262 \\
292\end{array}$ & $\begin{array}{l}2436 \\
2758\end{array}$ \\
\hline 17 & $\begin{array}{l}81.45 \\
82.82\end{array}$ & -29.12 & -25 & $\begin{array}{l}262 \\
292\end{array}$ & $\begin{array}{l}4263 \\
4776\end{array}$ \\
\hline $0_{0}^{18}$ & $\begin{array}{l}81.65 \\
82.91\end{array}$ & -26.86 & -27 & $\begin{array}{l}262 \\
292\end{array}$ & $\begin{array}{l}10831 \\
12077\end{array}$ \\
\hline 19 & $\begin{array}{l}90.69 \\
92.00\end{array}$ & -27.81 & -25 & $\begin{array}{l}262 \\
292\end{array}$ & $\begin{array}{l}14193 \\
15827\end{array}$ \\
\hline 20 & $\begin{array}{l}83.31 \\
84.53\end{array}$ & -25.79 & -23 & $\begin{array}{l}262 \\
292\end{array}$ & $\begin{array}{l}12985 \\
14489\end{array}$ \\
\hline 21 & $\begin{array}{l}74.45 \\
76.61\end{array}$ & -24.59 & -20 & $\begin{array}{l}262 \\
292\end{array}$ & $\begin{array}{l}6672 \\
8207\end{array}$ \\
\hline
\end{tabular}


Appendix (continued)

2.

August 23,1970 , recording 1 .

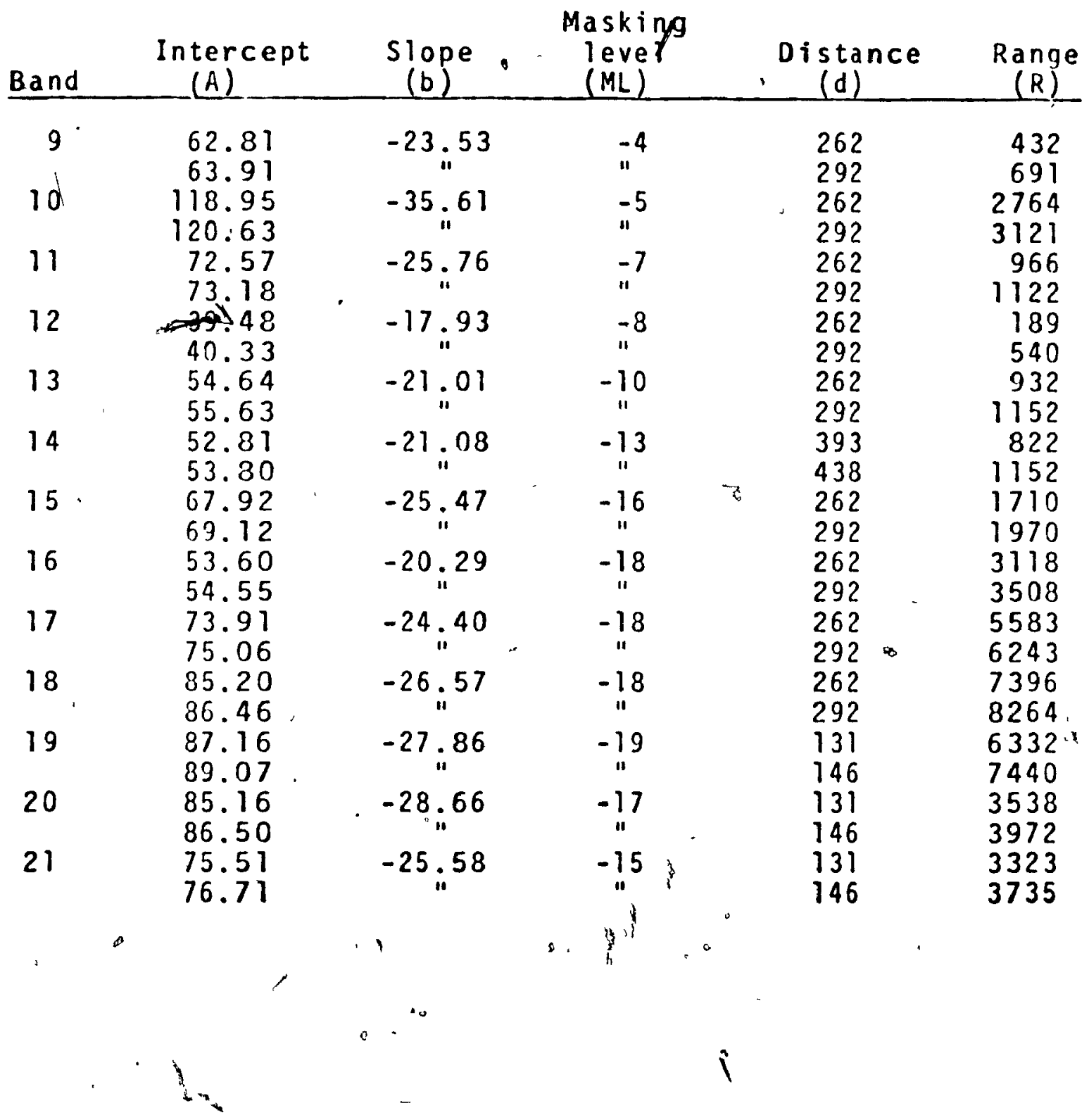


- Appendix (continued)

August 27, 1970, recording 1.

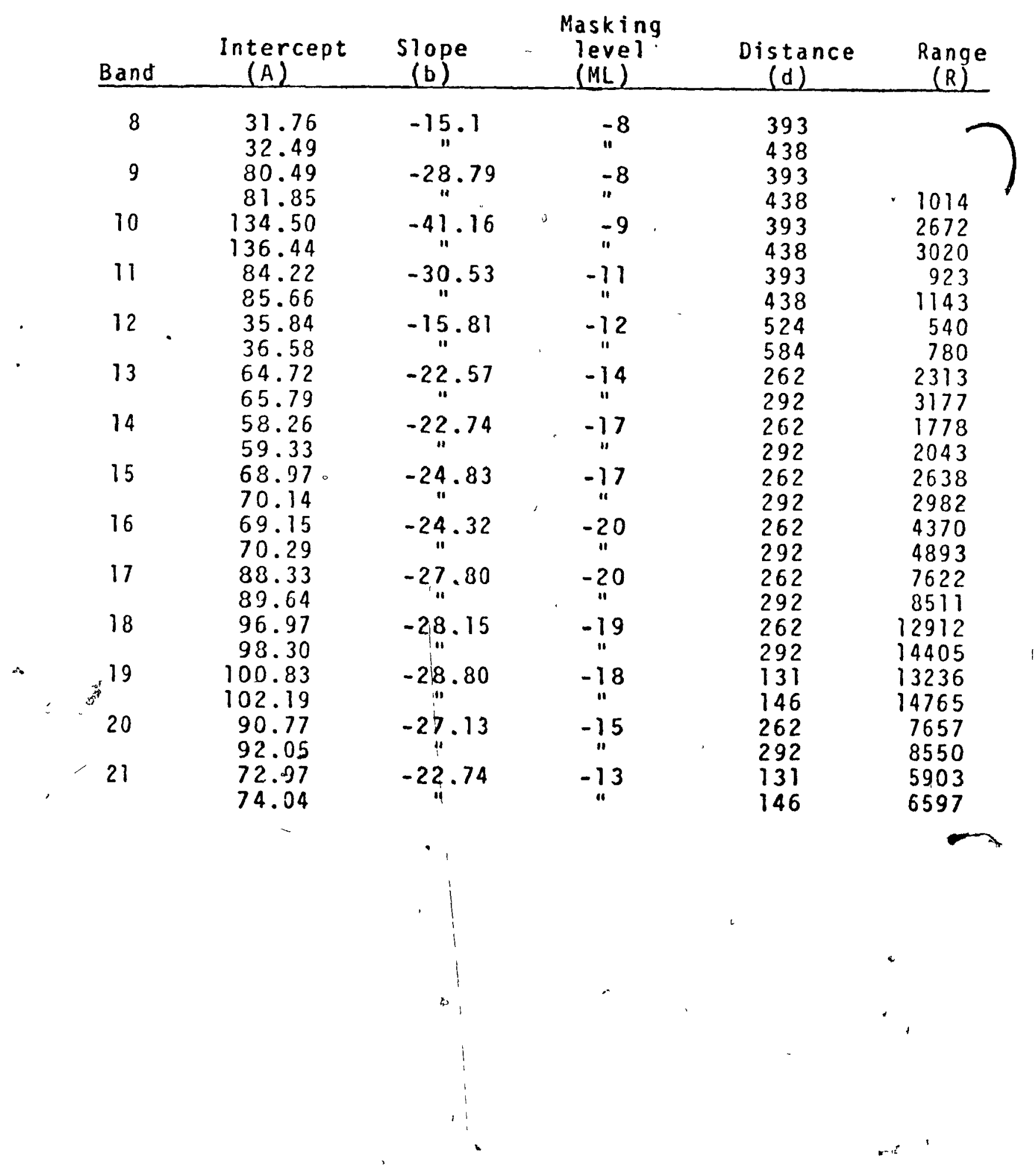


Appendix (continued)

4.

August 29,1970 , recording 2 .

\begin{tabular}{|c|c|c|c|c|c|}
\hline Band & $\begin{array}{c}\text { Intercept } \\
(A)\end{array}$ & $\begin{array}{c}\text { Slope } \\
\text { (b) }\end{array}$ & $\begin{array}{c}\text { Masking } \\
\text { level } \\
\text { (ML). }\end{array}$ & $\begin{array}{l}\text { Distance } \\
\text { (d) }\end{array}$ & $\begin{array}{c}\text { Range } \\
(R)\end{array}$ \\
\hline 8 & $\begin{array}{l}42.24 \\
43.23\end{array}$ & -20.97 & -9 & $\begin{array}{l}131 \\
146\end{array}$ & $\begin{array}{l}155 \\
526\end{array}$ \\
\hline 9 & $\begin{array}{l}91.21 \\
92.81\end{array}$ & $-34 i^{03}$ & -9 & $\begin{array}{l}131 \\
146\end{array}$ & $\begin{array}{l}751 \\
973\end{array}$ \\
\hline 10 & $\begin{array}{l}50.80 \\
51.63\end{array}$ & -17.67 & -10 & $\begin{array}{l}262 \\
292\end{array}$ & $\begin{array}{l}2498 \\
2827\end{array}$ \\
\hline 11 & $\begin{array}{l}89.02 \\
90.57\end{array}$ & $-32,96$ & -12 & $\begin{array}{l}262 \\
292\end{array}$ & $\begin{array}{r}900 \\
1120\end{array}$ \\
\hline 12 & $\begin{array}{l}61.47 \\
62.62\end{array}$ & -24.34 & -13 & $\begin{array}{l}262 \\
292\end{array}$ & $\begin{array}{r}886 \\
1106\end{array}$ \\
\hline 13 & $\begin{array}{l}26.74 \\
27.39\end{array}$ & -13.86 & -15 & $\begin{array}{l}131 \\
146\end{array}$ & $\begin{array}{r}897 \\
1116\end{array}$ \\
\hline 14 & $\begin{array}{l}70.66 \\
71.93\end{array}$ & -27.01 & -18 & $\begin{array}{l}131 \\
146\end{array}$ & $\begin{array}{l}1786 \\
2051\end{array}$ \\
\hline 15 & $\begin{array}{l}70.44 \\
71.66\end{array}$ & -25.85 & -19 & $\begin{array}{l}262 \\
292\end{array}$ & $\begin{array}{l}2622 \\
2965\end{array}$ \\
\hline 16 & $\begin{array}{l}84.29 \\
85.38\end{array}$ & -27.26 & -17 & $\begin{array}{l}262 \\
292\end{array}$ & $\begin{array}{l}4935 \\
5429\end{array}$ \\
\hline 17 & $\begin{array}{l}96.90 \\
98.39\end{array}$ & -31.74 & -14 & $\begin{array}{r}262 \\
-292\end{array}$ & $\begin{array}{l}2857 \\
3222\end{array}$ \\
\hline 18 & $\begin{array}{l}98.37 \\
99.76\end{array}$ & -29.42 & -12 & $\begin{array}{l}131 \\
146\end{array}$ & $\begin{array}{l}5512 \\
6166\end{array}$ \\
\hline 19 & $\begin{array}{l}115.02 \\
116.25\end{array}$ & -30.77 & -10 & $\begin{array}{l}131 \\
146\end{array}$ & $\begin{array}{l}11432 \\
12541\end{array}$ \\
\hline 20 & $\begin{array}{l}96.76 \\
98.12\end{array}$ & -28.99 & ${ }^{-7}$ & $\begin{array}{l}131 \\
146\end{array}$ & $\begin{array}{l}3664 \\
4112\end{array}$ \\
\hline 21 & $\begin{array}{l}81.07 \\
82.28\end{array}$ & -25.65 & ${ }^{-5}$ & $\begin{array}{l}131 \\
146\end{array}$ & $\begin{array}{l}2137 \\
2434\end{array}$ \\
\hline
\end{tabular}


Appendix (continued)

August 29,1970 , recording 3 .

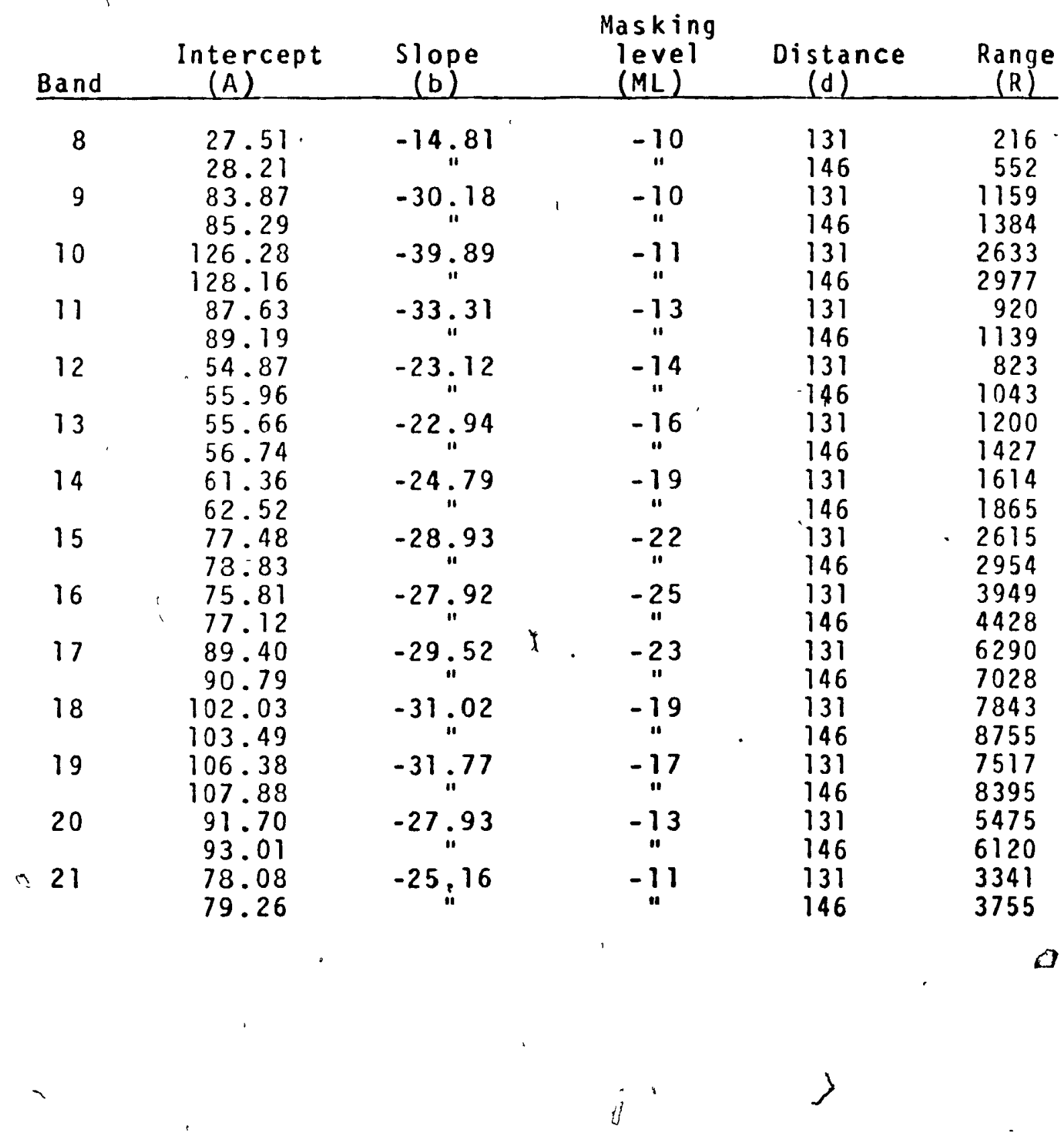


Appendix (continued)

October 21, 1970, recording 1 .

\begin{tabular}{|c|c|c|c|c|c|}
\hline Band & $\begin{array}{c}\text { Intercept } \\
(A)\end{array}$ & $\begin{array}{c}\text { Slope } \\
\text { (b) }\end{array}$ & $\begin{array}{c}\text { Masking } \\
\text { level } \\
(M L)\end{array}$ & $\begin{array}{l}\text { Distance } \\
\text { (d) }\end{array}$ & $\begin{array}{c}\text { Range } \\
(R)\end{array}$ \\
\hline 8 & $\begin{array}{l}35.29 \\
36.11\end{array}$ & $-17 i^{33}$ & -14 & $\begin{array}{l}262 \\
292\end{array}$ & $\begin{array}{l}439 \\
698\end{array}$ \\
\hline 9 & $\begin{array}{l}93.37 \\
95.00\end{array}$ & -34.59 & -16 & $\begin{array}{l}262 \\
292\end{array}$ & $\begin{array}{l}1191 \\
1417\end{array}$ \\
\hline $10:$ & $\begin{array}{l}130.36 \\
132.28\end{array}$ & -40.85 & -16 & $\begin{array}{l}262 \\
292\end{array}$ & $\begin{array}{l}3565 \\
4004\end{array}$ \\
\hline 11 & $\begin{array}{r}35.39 \\
97.06\end{array}$ & $-35_{i} .37$ & -17 & $\begin{array}{l}262 \\
292\end{array}$ & $\begin{array}{l}1244 \\
1473\end{array}$ \\
\hline 12 & $\begin{array}{l}65.57 \\
66.84\end{array}$ & -26.92 & -19 & $\begin{array}{r}262 \\
292\end{array}$ & $\begin{array}{l}1224 \\
1348\end{array}$ \\
\hline 13 & $\begin{array}{l}66.58 \\
67.81\end{array}$ & -26.27 & -21 & $\begin{array}{l}131 \\
146\end{array}$ & $\begin{array}{l}2027 \\
2311\end{array}$ \\
\hline 14 & $\begin{array}{l}70.19 \\
71.46\end{array}$ & -27.14 & -20 & $\begin{array}{l}131 \\
146\end{array}$ & $\begin{array}{l}1974 \\
2254\end{array}$ \\
\hline 15 & $\begin{array}{l}73.14 \\
74.42\end{array}$ & -27.27 & -19 & $\begin{array}{l}131 \\
146\end{array}$ & $\begin{array}{l}2262 \\
2568\end{array}$ \\
\hline 16 & $\begin{array}{l}47.20 \\
47.99\end{array}$ & -16.70 & -19 & $\begin{array}{l}131 \\
146\end{array}$ & $\begin{array}{r}9075 \\
10132\end{array}$ \\
\hline 17 & $\begin{array}{l}80.13 \\
81.35\end{array}$ & $-25_{i i} 77$ & -19 & $\begin{array}{l}131 \\
146\end{array}$ & $\begin{array}{l}6895 \\
7706\end{array}$ \\
\hline 18 & $\begin{array}{l}101.82 \\
103.26\end{array}$ & -30.57 & -20 & $\begin{array}{l}131 \\
146\end{array}$ & $\begin{array}{r}9529 \\
10632\end{array}$ \\
\hline 19 & $\begin{array}{l}110.72 \\
112.28\end{array}$ & -33.14 & -23 & $\begin{array}{l}131 \\
146\end{array}$ & $\begin{array}{l}10709 \\
11945\end{array}$ \\
\hline 20 & $\begin{array}{r}105.90 \\
107.49\end{array}$ & $-33 \times 4$ & -25 & $\begin{array}{l}131 \\
146\end{array}$ & $\begin{array}{l}7571 \\
8455\end{array}$ \\
\hline 21 & $\begin{array}{l}95.51 \\
96.98\end{array}$ & -31.33 & -25 & $\begin{array}{l}131 \\
146\end{array}$ & $\begin{array}{l}6891 \\
7694\end{array}$ \\
\hline
\end{tabular}


Appendix (continued)

January 7 , 1971, recording 1.

\begin{tabular}{|c|c|c|c|c|c|}
\hline Band & $\begin{array}{c}\text { In tercept } \\
(\mathrm{A})\end{array}$ & $\begin{array}{l}\text { slope } \\
\text { (b) }\end{array}$ & $\begin{array}{c}\text { Masking } \\
\text { level } \\
\text { (ILL) }\end{array}$ & $\begin{array}{l}\text { Distance } \\
\text { (d) }\end{array}$ & $\begin{array}{c}\text { Ranqe } \\
(R)\end{array}$ \\
\hline 9 & $\begin{array}{l}46.20 \\
47.02\end{array}$ & -17.43 & ${ }^{-3}$ & $\begin{array}{r}262 \\
.292\end{array}$ & $\begin{array}{l}406 \\
672\end{array}$ \\
\hline 10 & $\begin{array}{l}87.59 \\
88.71\end{array}$ & -23.87 & $i^{-4}$ & $\begin{array}{l}262 \\
292\end{array}$ & $\begin{array}{l}6609 \\
7380\end{array}$ \\
\hline 11 & $\begin{array}{l}68.07 \\
69.06\end{array}$ & -21.11 & -6 & $\begin{array}{l}262 \\
292\end{array}$ & $\begin{array}{l}2965 \\
3340\end{array}$ \\
\hline 12 & $\begin{array}{l}33.91 \\
34.56\end{array}$ & -13.82 & ${ }^{-7}$ & $\begin{array}{l}393 \\
438\end{array}$ & $\begin{array}{l}522 \\
764\end{array}$ \\
\hline 13 & $\begin{array}{l}40.26 \\
40.92\end{array}$ & -1.4 .01 & $i^{-7}$ & $\begin{array}{l}131 \\
146\end{array}$ & $\begin{array}{l}2232 \\
2537\end{array}$ \\
\hline 14 & $\begin{array}{l}23.92 \\
24.41\end{array}$ & -10.39 & $\begin{array}{l}-10 \\
11\end{array}$ & $\begin{array}{l}131 \\
146\end{array}$ & $\begin{array}{l}1709 \\
1969\end{array}$ \\
\hline 15 & $\begin{array}{l}52.65 \\
53.55\end{array}$ & -19.09 & -10 & $\begin{array}{l}262 \\
292\end{array}$ & $\begin{array}{l}1652 \\
1908\end{array}$ \\
\hline 16 & $\begin{array}{l}55.37 \\
56.23\end{array}$ & $-18 i_{i} 32$ & ${ }^{-9}$ & $\begin{array}{l}262 \\
292\end{array}$ & $\begin{array}{l}3002 \\
3381\end{array}$ \\
\hline 17 & $\begin{array}{l}76.11 . \\
77.21\end{array}$ & $-23_{i} 38$ & ${ }^{-8}$ & $\begin{array}{l}262 \\
292\end{array}$ & $\begin{array}{l}3697 \\
4150\end{array}$ \\
\hline 18 & $\begin{array}{l}80.30 \\
81.43\end{array}$ & $-24_{i} .02$ & ${ }^{-7}$ & $\begin{array}{l}393 \\
438\end{array}$ & $\begin{array}{l}3917 \\
4394\end{array}$ \\
\hline 19 & $\begin{array}{l}64.83 \\
65.77\end{array}$ & -19.95 & $i^{-5}$ & $\begin{array}{l}524 \\
584\end{array}$ & $\begin{array}{l}2641 \\
2985\end{array}$ \\
\hline 20 & $\begin{array}{l}55.63 . \\
56.46\end{array}$ & -17.61 & $7^{-3}$ & $\begin{array}{l}262 \\
292\end{array}$ & $\begin{array}{l}1873 \\
2147\end{array}$ \\
\hline 21 & $\begin{array}{l}46.32 \\
46.99\end{array}$ & -14.21 & ${ }^{-1}$ & $\begin{array}{l}393 \\
438\end{array}$ & $\begin{array}{l}1746 \\
2009\end{array}$ \\
\hline
\end{tabular}


Appendtx (continued)

January 7, 1971, recording 2 .

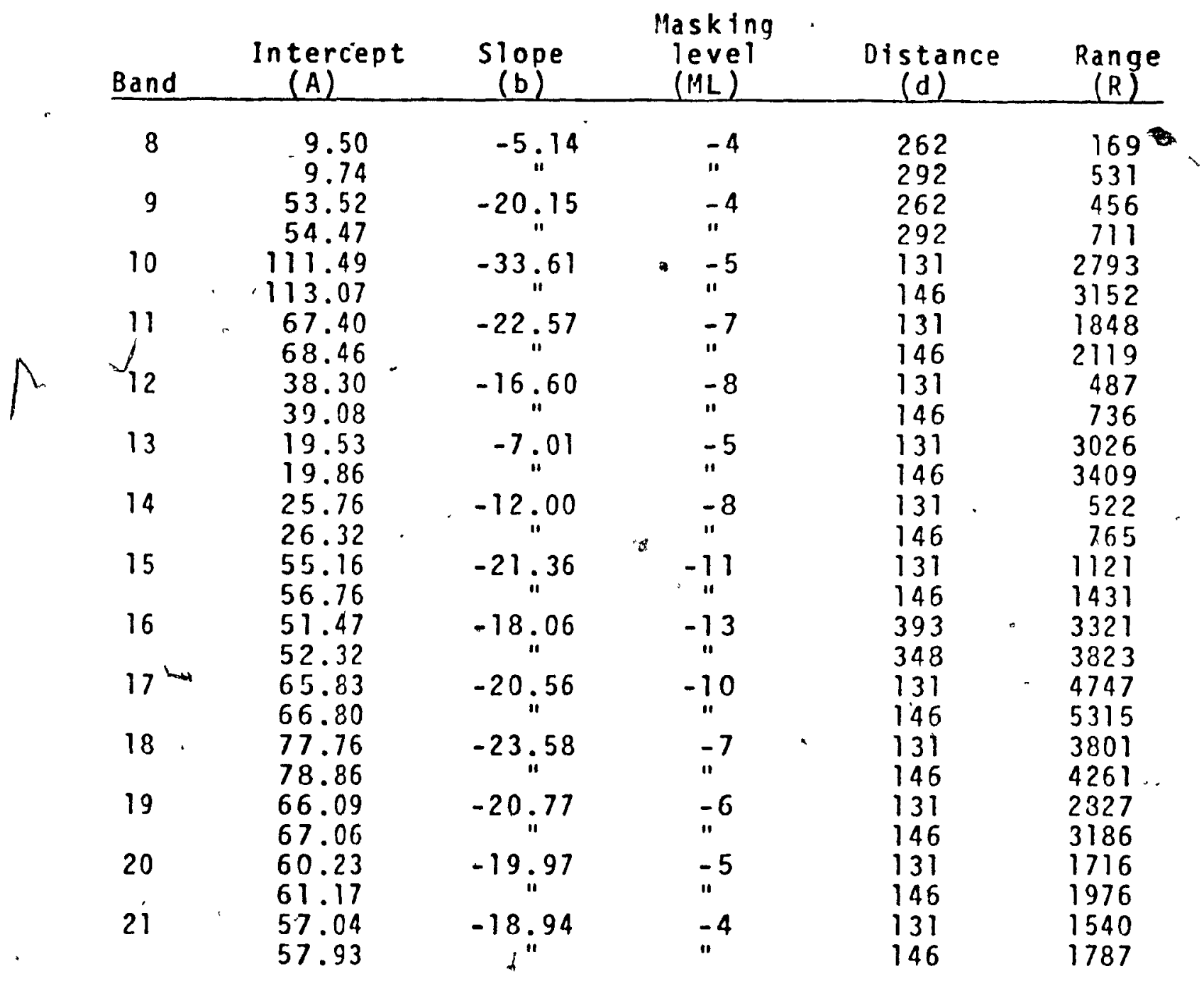


Appendix (continued)

January 7,1971 , recording 3 .

\begin{tabular}{|c|c|c|c|c|c|}
\hline Band & $\begin{array}{c}\text { Intercept } \\
(\mathrm{A})\end{array}$ & $\begin{array}{c}\text { slope } \\
\text { (b) }\end{array}$ & $\begin{array}{l}\text { Masking } \\
\text { level } \\
\text { (ML) }\end{array}$ & $\begin{array}{l}\text { Distance } \\
\text { (d) }\end{array}$ & $\begin{array}{c}\text { Range } \\
(R)\end{array}$ \\
\hline 9 & $\begin{array}{l}29.54 \\
30.10\end{array}$ & -11.94 & ${ }^{-3}$ & $\begin{array}{l}131 \\
146\end{array}$ & $\begin{array}{l}403 \\
670\end{array}$ \\
\hline 10 & $\begin{array}{l}95.30 \\
96.58\end{array}$ & -27.31 & $-^{-3}$ & $\begin{array}{l}131 \\
146\end{array}$ & $\begin{array}{l}3845 \\
4312\end{array}$ \\
\hline 11 & $\begin{array}{l}35.56 \\
36.10\end{array}$ & $-11,42$ & $-^{-5}$ & $\begin{array}{l}131 \\
146\end{array}$ & $\begin{array}{l}3431 \\
3858\end{array}$ \\
\hline 12 & 14.40 & $-7 i^{99}$ & -6 & $\begin{array}{l}131 \\
146\end{array}$ & $\begin{array}{r}.232 \\
560\end{array}$ \\
\hline 13 & $\begin{array}{l}36.96 \\
37.60\end{array}$ & -13.67 & -8 & $\begin{array}{l}262 \\
292\end{array}$ & $\begin{array}{l}1683 \\
1940\end{array}$ \\
\hline 14 & $\begin{array}{l}25.32 \\
25.83\end{array}$ & -10.70 & -7 & $\begin{array}{l}262 \\
292\end{array}$ & $\begin{array}{r}788 \\
1010\end{array}$ \\
\hline 15 & $\begin{array}{l}20.14 \\
20.53\end{array}$ & -8.33 & ${ }^{-8}$ & $\begin{array}{l}131 \\
146\end{array}$ & $\begin{array}{l}2258 \\
2564\end{array}$ \\
\hline 16 & $\begin{array}{l}41.27 \\
41.93\end{array}$ & -14.08 & -7 & $\begin{array}{l}2622^{\circ} \\
292\end{array}$ & $\begin{array}{l}2419 \\
2740\end{array}$ \\
\hline 17 & $\begin{array}{l}55.28 \\
56.06\end{array}$ & -16.67 & -5 & $\begin{array}{l}131 \\
146\end{array}$ & $\begin{array}{l}4001 \\
4483\end{array}$ \\
\hline 18 & $\begin{array}{l}59.75 \\
60.56\end{array}$ & $-17 i^{39}$ & $n^{-4}$ & $\begin{array}{l}131 \\
146\end{array}$ & $\begin{array}{l}4503 \\
5037\end{array}$ \\
\hline 19 & $\begin{array}{l}46.07 \\
46.71\end{array}$ & $=-13.58$ & ${ }^{-2}$ & $\begin{array}{l}131 \\
146\end{array}$ & $\begin{array}{l}3335 \\
3750\end{array}$ \\
\hline 20 & $\begin{array}{l}29.68 \\
30.10\end{array}$ & -8.86 & ${ }^{0}$ & $\begin{array}{r}131 \\
+\quad 145\end{array}$ & $\begin{array}{l}2108 \\
2403\end{array}$ \\
\hline 21 & $\begin{array}{l}30.12 \\
30.54\end{array}$ & -8.86 & $\begin{array}{l}+1 \\
\text { "1 }\end{array}$ & $\begin{array}{l}262 \\
292\end{array}$ & $\begin{array}{l}1674 \\
1932\end{array}$ \\
\hline
\end{tabular}




\section{Appendix (continued)}

January $21, \cdot 1971$, recording 1 .

\begin{tabular}{|c|c|c|c|c|c|c|}
\hline Band & $\begin{array}{c}\text { Intercept } \\
\text { (A) }\end{array}$ & $\begin{array}{l}\text { Slope } \\
\text { (b) }\end{array}$ & $\begin{array}{c}\text { Masking } \\
\text { leve } 1 \\
\text { (ML) }\end{array}$ & & $\begin{array}{c}\text { Distance } \\
\text { (d) }\end{array}$ & $\begin{array}{c}\text { Range } \\
\text { (R) }\end{array}$ \\
\hline 8 & $\begin{array}{l}-6.59 \\
-6.47\end{array}$ & -2.72 & -9 & & $\begin{array}{l}524 \\
584\end{array}$ & \\
\hline 9 & $\begin{array}{r}42.17 \\
42.97\end{array}$ & -16.96 & -9 & & $\begin{array}{l}393 \\
438\end{array}$ & $\begin{array}{l}649 \\
878\end{array}$ \\
\hline 10 & $\begin{array}{l}113.39 \\
115.03^{\circ}\end{array}$ & $-34 i 74$ & $\begin{array}{l}-7 \\
11\end{array}$ & & $\begin{array}{l}393 \\
438\end{array}$ & $\begin{array}{l}2528 \\
2862\end{array}$ \\
\hline 11 & $\begin{array}{l}84.28 \\
85.57\end{array}$ & -27.57 & $\begin{array}{l}-4 \\
11\end{array}$ & & $\begin{array}{l}393 \\
438\end{array}$ & $\begin{array}{l}1200 \\
1426\end{array}$ \\
\hline 12 & $\begin{array}{l}13.10 \\
13.44\end{array}$ & -7.11 & $\begin{array}{l}-1 \\
11\end{array}$ & & $\begin{array}{l}131 \\
146\end{array}$ & \\
\hline 13 & $\begin{array}{l}37.43 \\
37.97\end{array}$ & -11.44 & $\begin{array}{l}+3 \\
" 1\end{array}$ & & $\begin{array}{l}131 \\
146\end{array}$ & $\begin{array}{r}893 \\
1112\end{array}$ \\
\hline 14 & 23.81 & -9.40 & ${ }^{0}$ & & 131 & 216 \\
\hline 15 & $\begin{array}{l}24.25 \\
53.39 \\
54.29\end{array}$ & $-19: 13$ & -3 & 1 & $\begin{array}{l}146 \\
262 \\
292\end{array}$ & $\begin{array}{l}552 \\
627 \\
857\end{array}$ \\
\hline 16 & $\begin{array}{l}56.06 \\
5.6 .95\end{array}$ & $-18,97$ & -7 & & $\begin{array}{l}655 \\
730\end{array}$ & $\begin{array}{l}1455 \\
1696\end{array}$ \\
\hline 17 & $\begin{array}{l}68.60 \\
69.59\end{array}$ & $-21,00$ & $\cdots-12$ & $\therefore$ & $\begin{array}{l}131 \\
146\end{array}$ & $\begin{array}{l}6757 \\
7548\end{array}$ \\
\hline 18 & $\begin{array}{l}55.41 \\
56.20\end{array}$ & -16.81 & $\begin{array}{l}-12 \\
11\end{array}$ & & $\begin{array}{l}655 \\
730\end{array}$ & $\begin{array}{r}9580 \\
10687\end{array}$ \\
\hline 19 & $\begin{array}{l}48.28 \\
48.98\end{array}$ & $-15,08$ & -11 & & $\begin{array}{l}655 \\
730\end{array}$ & $\begin{array}{l}7876 \\
8778\end{array}$ \\
\hline 20 & $\begin{array}{l}54.97 \\
55.82\end{array}$ & $-18,10$ & -9 & ${ }^{\circ}$ & $\begin{array}{l}655 \\
730\end{array}$ & $\begin{array}{l}2767 \\
3123\end{array}$ \\
\hline 21 & $\begin{array}{l}53.67 \\
54.51\end{array}$ & $-17 i^{95}$ & -10 & & $\begin{array}{l}131 \\
146\end{array}$ & $\begin{array}{r}3394 \\
3812\end{array}$ \\
\hline
\end{tabular}


Appendix (continued)

$\sim^{\text {January } 21,1971 \text {, recording } 2 .}$

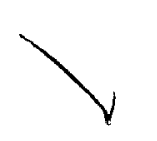

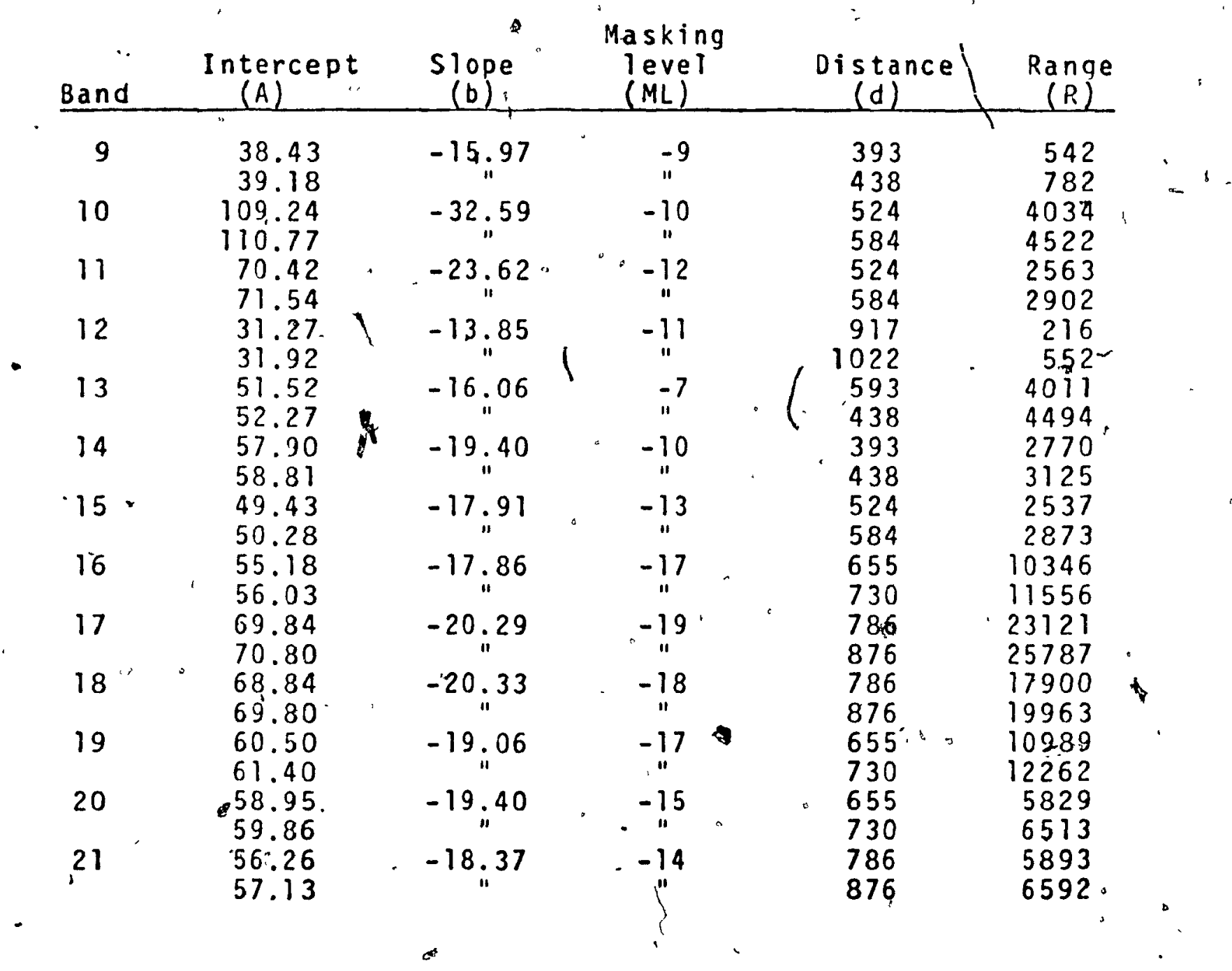

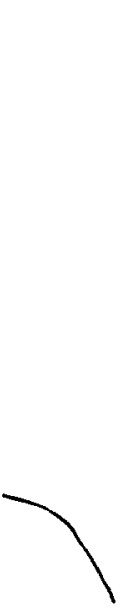


January 22; 1971 , recording $1:$

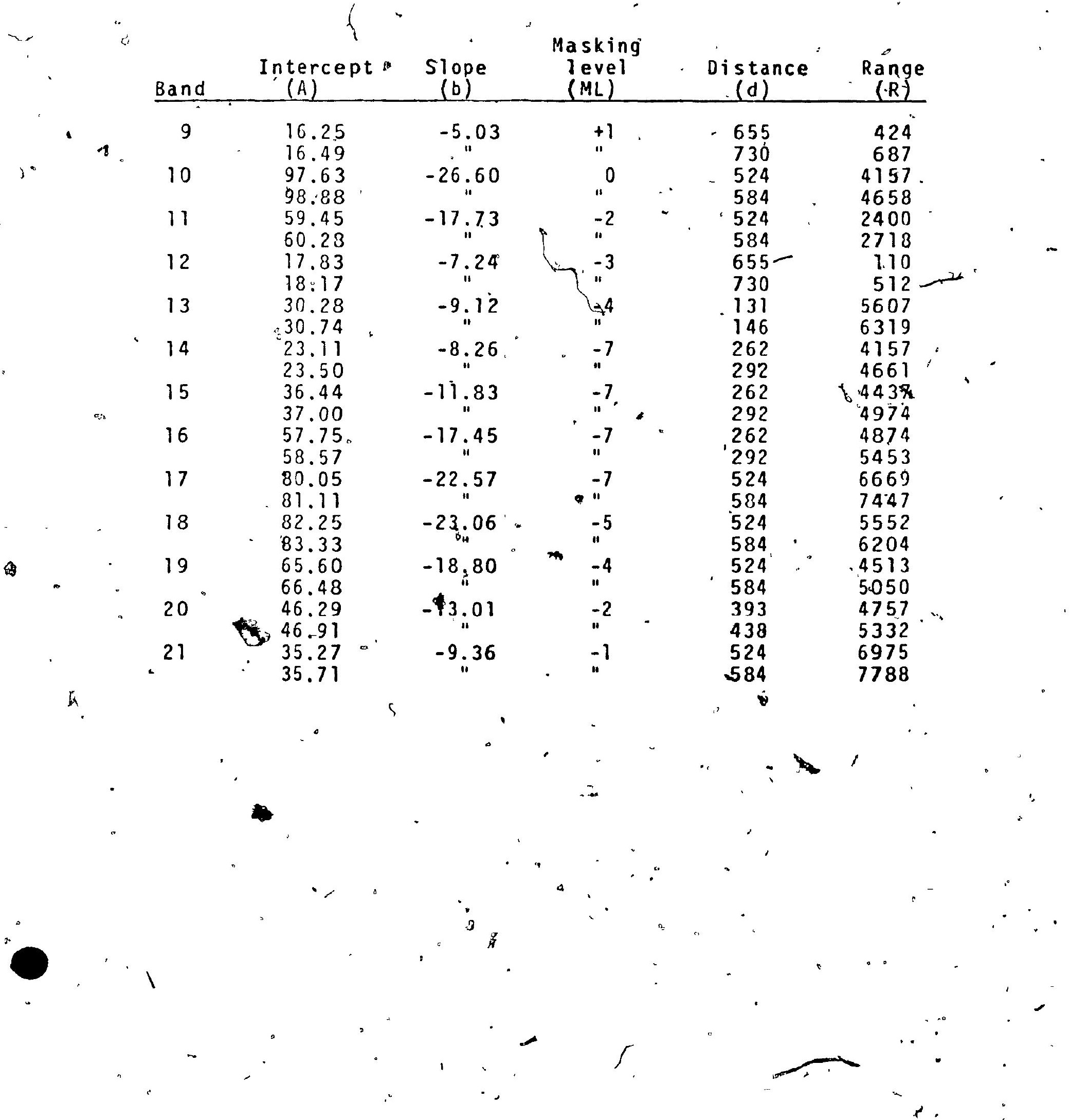

